\title{
Tracking biases in the regular echinoid fossil record: The case of Paracentrotus lividus in recent and fossil shallow-water, high-energy environments
}

\author{
Andrea Mancosu and James H. Nebelsick
}

\begin{abstract}
The poor fossil record of regular echinoids is commonly attributed to the fact that they preferentially live as epibenthic grazers on hard rocky substrates in nearshore environments with high energy conditions, where the preservation potential of their tests is generally low. In addition, they commonly occur in the fossil record as fragmented material that hampers identification to low taxonomic level. Herein, a comparative analysis of fossil and recent remains of the regular sea urchin Paracentrotus lividus has been conducted, in order to evaluate the source of taphonomic and taxonomic biases affecting regular echinoid remains.

Echinoid remnants are recognized in great abundance both in the Upper Pleistocene marine deposit of Is Mesas and recent littoral environments of Sa Mesa Longa, both in Sardinia (Italy). They were rigorously categorized and analysed with respect to relative abundance, biostratinomic signatures and constructional detail of the skeleton using scanning electron microscopy. Paracentrotus remnants mainly consist of test fragments, isolated plates and fragmented spines. Plates of the apical system and elements of the jaw apparatus were also found.

Echinoid remnants in the Pleistocene deposit reflect those in recent environment, with respect to relative abundance and biostratinomic features, and are useful tools for paleoenvironmental and paleoecological reconstruction, even in shallow-water, highenergy environments. The abundance of large test fragments of Paracentrotus lividus both in the Pleistocene record and recent environments is due to a relatively robust test and stereomic interlocking. Difference in relative abundance of echinoid remains and their distribution in sediment fractions (>2 mm and 1-2 $\mathrm{mm}$ ) are due to different sampling methods, but also indicate the different preservation potential among various test elements. Herein, the identification of echinoid remains at a low taxonomic level can be assessed even at a very-coarse sand-size fraction (1-2 $\mathrm{mm})$. This study demonstrates that regular echinoid fragments can be identified to a low taxonomic level when very
\end{abstract}

Mancosu, Andrea and Nebelsick, James H. 2020. Tracking biases in the regular echinoid fossil record: The case of Paracentrotus lividus in recent and fossil shallow-water, high-energy environments. Palaeontologia Electronica, 23(2):a42. https://doi.org/10.26879/ 1090

palaeo-electronica.org/content/2020/3132-taphonomy-regular-echinoids

Copyright: August 2020 Paleontological Society.

This is an open access article distributed under the terms of Attribution-NonCommercial-ShareAlike 4.0 International (CC BY-NC-SA 4.0), which permits users to copy and redistribute the material in any medium or format, provided it is not used for commercial purposes and the original author and source are credited, with indications if any changes are made.

creativecommons.org/licenses/by-nc-sa/4.0/ 
specific characters are preserved, and their analysis may help to minimize the taxonomic bias affecting the regular echinoid fossil record.

Andrea Mancosu. Dipartimento di Scienze Chimiche e Geologiche, Università degli Studi di Cagliari. andrea.mancosu@gmail.com

James H. Nebelsick. Department of Geosciences, University of Tübingen. nebelsick@uni-tuebingen.de

Keywords: Pleistocene; rocky substrate; echinoids; mollusks; taphonomy; taxonomy

Submission: 21 April 2020. Acceptance: 8 August 2020.

\section{INTRODUCTION}

\section{Skeletal Architecture, Ecology and Preservation}

The evolutionary history of echinoids and their paleoecology as deduced from the fossil record is biased by several factors. Preservational differences among echinoid taxa depend on skeletal architecture and organic connective tissues, lifestyles and the complex interplay of taphonomic processes affecting echinoid tests and spines (e.g., Smith, 1984; Allison, 1990; Kidwell and Baumiller, 1990; Greenstein, 1991, 1993a, 1993b, 1995; Nebelsick and Kampfer, 1994; Nebelsick, 1995; Moffat and Bottjer, 1999; Banno, 2008; Smith and Rader, 2009).

All echinoids possess a multi-plated mesodermal skeleton constructed by conjoined high-Mg calcite plates. Each skeletal element consists of a three-dimensional meshwork of mineralized trabeculae, the stereom, and of an organic component, represented by the connective tissue filling the pores of the stereom, the stroma (Smith, 1980, 1984; Kroh and Nebelsick, 2010; Grun and Nebelsick, 2018b). Test stability and thus preservation potential is determined by the degree of interlocking by stereom trabeculae of coronal plates at sutures and the presence of numerous collagenous fibers, which cross the sutures and bind the adjacent plates together (Smith, 1984; Donovan, 1991; Ellers et al., 1998; Grun and Nebelsick, 2018a; Grun et al., 2018a, b).

There is a wide spectrum of test architectures among echinoids and the rigidity of the test differs highly among evolutionary lineages (Smith, 2005, 2007). Among regular echinoids, camarodonts possess tests relatively more resistant to disarticulation having some degree of stereomic interlocking at plate suture faces (Régis, 1977, 1979; Telford, 1985; Dafni, 1986; Kidwell and Baumiller, 1990; Greenstein, 1991, 1995; Ellers et al., 1998). By contrast, echinothurioids and diadematoids have tests with no stereom connection between the plates, which are embedded in a meshwork of collagenous fibers and dissociate rapidly after soft tissue decay, especially when subjected to postmortem transportation and reworking (Smith, 1984; Greenstein, 1989, 1991, 1993a, 1993b), leading to low preservation potentials and a poor fossil record (Smith, 1984; Greenstein, 1991, 1995; Ellers et al., 1998). Cidaroid echinoids fall between these extremes (Kidwell and Baumiller, 1990; Greenstein, 1991).

Among irregular echinoids, clypeasteroids have the most extensive stereomic interlocking across plate boundaries and also possess internal supports, represented by different structural solutions, such as pillars in Clypeaster and buttresses in Echinocyamus, which conjoin the oral and aboral sides, leading to a high preservation of tests even in high energy settings (Kier 1977; Seilacher, 1979; Nebelsick and Kroh, 2002; Mitchell et al., 2006; Belaústegui et al., 2012; Mancosu and Nebelsick, 2013, 2017; Grun and Nebelsick, 2018a; Grun et al., 2018a,b; Nebelsick, 2020).

Besides differences in constructional morphology, preservation potential is related to differences in life habit and ecology among echinoids and, in turn, taphonomic processes affecting the echinoid test (Ernst and Seibertz, 1977; Kier, 1977; Smith, 1984; Greenstein, 1993a; Nebelsick, 1996). Irregular echinoids, since their appearance in the Early Jurassic, diversified as deposit feeders (Kier, 1982; Barras, 2008) often buried within mobile substrates in areas of net sedimentation where the preservation potential is generally higher (Smith, 1984; Nebelsick, 1996).

In contrast to irregular forms, regular echinoids live as epibenthic grazers in environments where their preservation potential is generally low and are less likely to be represented in the fossil record (Ernst and Seibert, 1977; Kier, 1977; Smith, 1984; Kidwell and Baumiller, 1990). 
Regular echinoids predominate in rocky intertidal shores and sheltered back-reef and peri-reefal shallow water environments. Rocky shores, and their associated faunas, are poorly preserved in the rock record due to the prevalence of high energy conditions and active erosion or non-deposition of sediments (see also Smith, 1984; Greenstein 1993a; Sørensen and Surlyk, 2015).

Regular echinoids living in these environments frequently suffer lethal and non-lethal damage and breakage that can be caused by impact from rolling cobbles and against rocks, where the echinoids can be dislodged, especially during storms (Ebert, 1968). Additionally, bioerosion and predation (Sievers and Nebelsick, 2018 and references cited therein) and post-mortem physical reworking and transportation leads to fragmentation of sea urchin tests resulting in isolated and broken plates and spines.

Actuopaleontological studies based on both experimental and field observations shed light on the taphonomic processes affecting regular echinoid tests. Experimental taphonomic investigations on regular echinoids conducted by Kidwell and Baumiller (1990) and Greenstein (1991, 1995) reveal that reworking can induce rapid disarticulation of spines and precludes the preservation of their fragile complete tests. The investigated echinoids, pertaining to cidaroids, diadematoids and camarodonts, show a similar sequence of skeletal disarticulation ranging from intact to completely disarticulated tests. There are, however, differences in the timing of disarticulation phases depending on skeletal architectures, namely the distribution of collagenous connective tissues, the degree of stereomic inter-digitation, and temperature and other ambient environmental conditions. Field investigations in recent environments are consistent with these results and document that the distribution of regular echinoid skeletal remains in shallow water environments accurately reflects living population when not only whole tests, but also isolated fragments are considered (Greenstein, 1989, 1992, 1993b; 1995; Nebelsick, 1992a, b, 1996; Lewis et al., 2000; Schein and Lewis, 2001; Dynowski, 2012).

The echinoid fossil record can furthermore be influenced by sampling methods and taxonomic methodology. Regular echinoids are often preserved as fragments meaning that taxonomists may have difficulty in identifying them at low taxonomic level. Taxonomic studies are largely restricted to well-preserved fully articulated specimens, due to the difficulty in the identification of taxa based on fragmentary material (e.g., Gordon and Donovan, 1992; Greenstein, 1991, 1993a, b). Some studies, however, have demonstrated the importance of including echinoid fragments for taxonomy (e.g., Smiser, 1933; Thompson et al., 2019), paleoecology (e.g., Gordon and Donovan, 1992; Thompson et al., 2019) and actualistic investigations (e.g., Nebelsick, 1992a, b; Schein and Lewis, 2001; Dynowski, 2012).

Herein, within an ongoing evaluation of the preservation of echinoids and the nature of their fossil record, a comparative study of the remains of the regular sea urchin Paracentrotus lividus from both the Late Pleistocene (Tarantian, MIS 5e) marine rocks and modern shore deposits of Sa Mesa Longa Beach, both in Sardinia (Italy), has been carried out. This study aims to rigorously quantify these remains, show in detail how skeletal architectures and morphological features and the presence of collagenous fibers affect specific preservation patterns, evaluate the source of biostratinomic and taxonomic biases affecting the remains, and reiterate the use of echinoid test fragments in paleoecological reconstructions.

\section{The Camarodont Echinoid Paracentrotus lividus}

The shallow water echinoid fauna in the Mediterranean is strictly controlled by substrate and other ecological factors (e.g., Koehler, 1927; Tortonese, 1965; Ernst et al., 1973; Riedl, 1983). Hard substrates in shallow water are characterized by the regular echinoids Paracentrotus lividus, Arbacia lixula and Sphaerechinus granularis, while Psammechinus miliaris is often associated with sea grass meadows. Shallow water soft substrates are characterized by Spatangus purpureus, Echinocardium (diverse species), Ova canaliferous and Echinocyamus pusillus which are controlled, among others, by the grain size of the sediment in which they live.

Paracentrotus lividus (Lamarck, 1816) is a camarodont parechinid regular echinoid, which has a general moderately low hemispherical test. Ambulacral plates are polygeminate with 5 to 6 pore-pairs to a plate arranged in arcs and one primary imperforate tubercle to each compound plates. Interambulacral plates have larger primary tubercles and one or more secondary tubercles on either side at the ambitus. Spines are relatively short, about half the test diameter in length, with the base bearing a crenulated milled ring and collar, shaft and tip with fine longitudinal striation (Smith and Kroh, 2011). 
Paracentrotus lividus is one of the most common regular echinoids of the Mediterranean and eastern Atlantic coasts of Europe and north Africa (Fernandez et al., 2012; Deli et al., 2017 and references therein) and inhabits littoral and shallow sublittoral, temperate to subtropical marine environments (Ernst et al., 1973; Turon et al., 1995; Boudouresque and Verlaque, 2007, 2020; Girard et al., 2011). P. lividus has a broad ecological distribution (Tortonese, 1965; Régis, 1979; Jacinto and Cruz, 2012), ranging from intertidal rock pools, coastal lagoons, and most commonly, in the shallow marine subtidal nearshore environment down to $20 \mathrm{~m}$ depth (Mortensen, 1927, 1943; Tortonese, 1965; Ebling et al., 1966; Verlaque, 1984, 1987; Fernandez et al., 2001, 2012).

\section{Pleistocene Marine Deposits of Sardinia}

Along the coasts of Sardinia, Upper Pleistocene marine deposits, related to the sea level highstand during the last interglacial period, extensively crop out and are found at heights up to $10 \mathrm{~m}$ above the current sea level (Ulzega and Ozer, 1982; Ulzega and Hearty, 1986; Carboni and Lecca, 1985; Barca et al., 2005; Lecca and Carboni, 2007; Carboni et al., 2014; Barca et al., 2016, 2017). These marine deposits pertain to the Calamosca (PVM1) subsynthem of the Portovesme (PVM) synthem (Barca et al., 2005, 2016, 2017). One of the best-known Late Pleistocene (Tarantian, MIS 5e) marine deposit is documented in the Bay of Cagliari (southern Sardinia), along the coast from Calamosca to Is Mesas (Latitude $39^{\circ} 11^{\prime} 00^{\prime \prime} \mathrm{N}$, Longitude $9^{\circ} 08^{\prime} 55^{\prime \prime} E$ ) (Figure $1 \mathrm{~A}$ ), that represents the type section of the Thyrrhenian Stage (Issel, 1914). This deposit lies on an abrasion platform cut onto the Upper Miocene (Tortonian) Limestones of Cagliari and consist of conglomerates and sandstones (Barca et al., 2005, 2017) containing a rich fossil invertebrate fauna and flora consisting of coralline algae.

The fossil content was first sampled by Lovisato and subsequently studied by Issel (1914) who established the "Piano Tirreno" (Tyrrhenian Stage) for the fossil-bearing deposit, which includes the characteristic and emblematic gastropod Persististrombus latus, previously known as Strombus bubonius. Subsequent studies improved the knowledge of the fossil fauna with respect to the taxonomy (Fontana Zanco, 1933; Comaschi Caria and Pastore, 1959; Comaschi Caria, 1968; Spano, 1982) and its paleoecological and paleoclimatic significance (Spano, 1993a, b). The fossil fauna is dominated by mollusks and the colonial scleractinian coral Cladocora caespitosa (Spano, 1993a, b). Together with a number of species commonly living in the Mediterranean today, such as Arca noae, and Patella ferruginea, these belong to a group of taxa traditionally called "Senegalese guests" or "warm visitors", including Persististrombus latus,

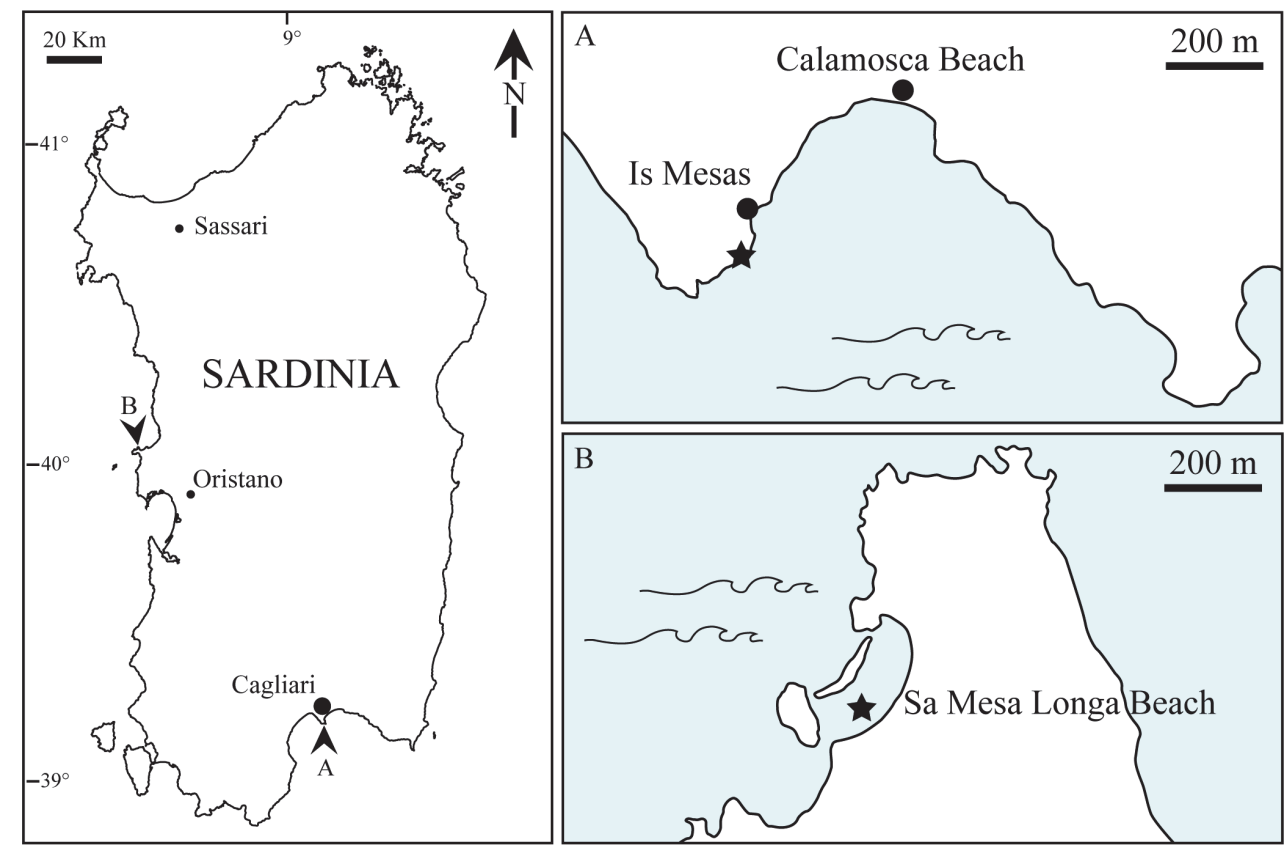

FIGURE 1. Location of A, Late Pleistocene deposit of Is Mesas and B, Sa Mesa Longa Beach, Sardinia, Italy. 
Conus ermineus (syn. C. testudinarius) and Gemophos viverratus. These taxa still thrive in the tropics, especially in the warm coastal regions of West Africa, but are currently extinct in the Mediterranean (see Sessa et al., 2013 and references cited therein; Brunetti and Della Bella, 2014).

The age of these deposits has been debated (see Carboni et al., 2014 and references cited therein). Radiometric data using U/Th ratio on Cladocora caespitosa from Calamosca provided an age of $138 \pm 8 \mathrm{ka}$ (Ulzega and Hearthy, 1986). More recently, U/Th dating on Cladocora caespitosa from the same locality provided an age of $122.3 \pm 5$ ka for these deposits (Barca et al., 2005) which therefore pertain to MIS 5e (Marine Isotopic Stage $5 \mathrm{e}, \sim 130 \mathrm{ka}$ to $\sim 116 \mathrm{ka}$ ), the warmest interval of the Interglacial period (Rohling et al., 2007). This age is consistent with $\mathrm{U} / \mathrm{Th}$ dating on Caldocora caespitosa colonies from the Upper Pleistocene deposits of San Giovanni di Sinis (Central-western Sardnia), the age of which is $128 \pm 4$ ka (Carboni et al., 2014).

\section{Recent Collections from Sa Mesa Longa Beach}

The Sa Mesa Longa Beach (Latitude $40^{\circ}$ $02^{\prime} 47^{\prime \prime} \mathrm{N}$, Longitude $8^{\circ} 23^{\prime} 57^{\prime \prime} \mathrm{E}$ ) on the central west coast of Sardinia is located on the Capo Mannu Cape (Oristano Province) (Figure 1B). Sa Mesa Longa ("the long table" in Sardinian language) is a pocket beach extending for approximately $1200 \mathrm{~m}$ between two headlands and is characterized in its central part by a salient shape due to a rocky reef located approximately $100 \mathrm{~m}$ from the baseline. Two main wave directions are consistently predominant in magnitude and frequency: $310-340^{\circ} \mathrm{N}$ and $230-260^{\circ} \mathrm{N}$, corresponding to the Maestrale (from northwest) and Libeccio (from southwest) winds in the Mediterranean Sea, respectively (Sulis and Annis, 2014). A variety of marine substrates occurs, including rocks and mobile sediments, which mainly consist of very coarse to coarsegrained bioclastic sands with pebbles and cobbles. Patches of the seagrass Posidonia oceanica also occur. Coralline algae rhodoliths are also present.

\section{MATERIAL AND METHODS}

Field and laboratory investigations at is Mesas were conducted with respect to paleontology, taphonomy and sedimentology. The frequency of echinoid remains was estimated per rock surface. The degree of close-packing determined as dense, loose or dispersed follows Kidwell and Holland (1991). The density of echinoid remains on the bedding plane was estimated using a $50 \mathrm{~cm} \mathrm{x}$
$50 \mathrm{~cm}$ quadrat. Rock samples of poorly consolidated coarse-grained sandstones were collected from Level $A$ of the Pleistocene sedimentary deposit (Figure 2) in order to recover fossil remains. Approximately $8 \mathrm{~kg}$ of the soft sedimentary rocks was sampled and wet-sifted using sieves with $2 \mathrm{~mm}$ and $1 \mathrm{~mm}$ meshes. The resulting dried residue was rich in echinoid fragments in both sediment fractions and was inspected using a stereo microscope. Spine remains were picked up directly from rock samples under the microscope to avoid breakage during the sieving process.

Remains of the recent Paracentrotus lividus were collected at Sa Mesa Longa Beach (Figure 1B), Central-western Sardinia, on multiple occasions between 2018 and 2020. Echinoid remains were exhaustively searched and collected by manually picking them from the sediment surface by snorkelling in shallow water near-shore environment from the shoreline down to $2 \mathrm{~m}$ depth. The remains were recovered on the sediment surface near patches of seagrass (Posidonia oceanica) as well as on and around rocky substrates. Additionally, bulk sediment samples were collected by using a hand corer at a depth from 0.5 to $1 \mathrm{~m}$ for a total of $2 \mathrm{~kg}$ of sediments and processed by the same method adopted for the fossil remains.

Echinoid remains, both fossil and recent, including test and spine remains, were examined with respect to taphonomic signatures, notably fragmentation, abrasion and encrustation. The preservation of test features, such as tubercles on the test surfaces and the crenulation of spine milled ring along with striation of spine shaft, was used to evaluate abrasion.

In this study, the taphonomic bias affecting the echinoid skeletal elements is directly evaluated by comparing the observed and expected abundance of skeletal elements. This was done using the following calculation: (OA/EA) x 100, with OA representing the observed skeletal element abundance in the sample and EA representing the expected skeletal element abundance present within a complete skeleton.

Photographs of the retrieved fossil and recent echinoid remains were taken with a digital camera and a Leica DMS1000 digital microscope at the Department of Chemical and Geological Sciences, Cagliari, Italy. Fossil specimens were cleaned with a hypersonic bath (3 minutes). Scanning electron microscopy (SEM) was performed at the State Museum of Natural History, Stuttgart, Germany. Gold-palladium coating with a thickness of $8 \mathrm{~nm}$ was accomplished using a Leica EM ACE200. 


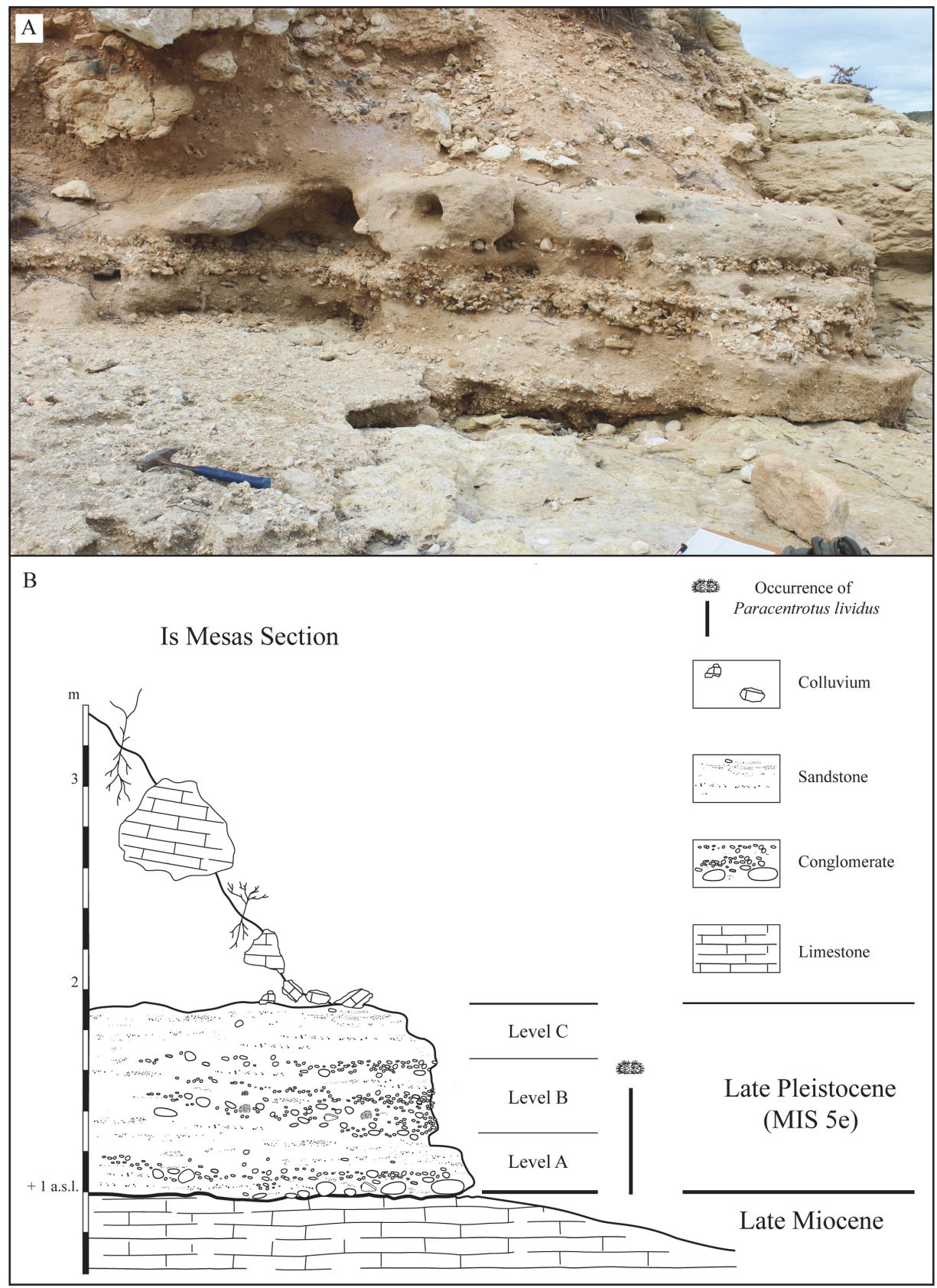

FIGURE 2. A, Field view of the Upper Pleistocene deposit of Is Mesas. B, Stratigraphic section of the deposit.

Scanning micrographs used a Zeiss EVO LS 15. Photos were enhanced (contrast, brightness), assembled and cut out using Adobe Photoshop (2019) and Adobe Illustrator (2018).

Echinoid classification at and above species level follows Kroh and Smith (2010) and Smith and Kroh (2011). Sutures are categorized according to Smith and Kroh (2011). Mollusk taxonomy follows WoRMS (World Register of Marine Species available at http://www.marinespecies.org/index.php). Samples are housed in the Museo di Geologia e
Paleontologia Domenico Lovisato, Università di Cagliari.

\section{RESULTS}

\section{Sedimentology and Paleontology}

The Upper Pleistocene marine deposit studied herein, which crops out in the locality Is Mesas, is approximately $1 \mathrm{~m}$ thick and overlies Upper Miocene, Tortonian pale yellow limestones, which pertain to the Calcari di Cagliari (Cagliari Limestones). 
The studied deposit can be subdivided into three different levels from the base to top (Figure 2). The first level (Level A in Figure 2) is ca. $40 \mathrm{~cm}$ thick and consists of a conglomerate, containing subangular to rounded clasts along with pebbles, cobbles and boulders with a maximum size of $20 \mathrm{~cm}$, gradually passing upward into a poorly sorted coarse to very coarse sandstone with abundant bioclasts. Clasts and pebbles consist predominantly of Miocene limestones and show bioerosion traces produced by endolithic bivalves (Gastrochaenolites) and clionid sponges (Entobia) and encrustation by coralline algae. Macrofossils are very abundant and are represented by the echinoid Paracentrotus lividus (Figure 3) and associated malacofauna (Table 1 and Figure 4). The remains of the coral Cladocora caespitosa and coralline algal rhodoliths also commonly occur. A single test fragment of the clypeasteroid echinoid Echinocyamus was found.

Level B consists of a matrix to clast-supported conglomerate with rounded pebbles and granules with an abundant fossil content similar to that of Level $A$. This conglomerate is surmounted by a medium to coarse sandstone (Level C) with floating pebbles and rare mollusk remains. The fossil remains in levels $A$ and $B$ are chaotically oriented in plan view and cross section and are not homogeneously distributed within the deposit, ranging from loosely packed and dispersed to very densely packed (sensu Kidwell and Holland, 1991).

Echinoid remains are very abundant (more than $500 / \mathrm{m}^{2}$ in Level A) and occur in a wide spectrum of preservation (Figures 3, 5 and Table 2-Part $1)$. They are represented by variously sized test pieces composed of several articulated plates to isolated ambulacral and interambulacral plates showing fragmentation within plates (interplate fragmentation) as well as along plate boundaries (disarticulation or intraplate fragmentation). Test fragments composed of articulated plates are often confined to single rows or in the case of larger fragments to the offset paired rows of ambulacra or interambulacra. Genital and ocular plates of the apical system also occur sporadically.

Test fragments of Paracentrotus lividus show differential preservation (Figures 3, 5 and Table 2Part 1). In better-preserved specimens, general morphological features of the surface such as primary and secondary tuberculation as well as paired ambulacral pores can be readily recognized. Generally, the edges of the plates are abraded and rounded. The stereom microstructure is largely obscured by recrystallization, but can be recog- nized on some surfaces. The interdigitating knobs on the plate edges, which can be easily seen on recent plates boundaries (see below), cannot be recognized. The surface morphology shows some pitting and abrasion, and some tubercles have been fragmented. In one case, a cavity of the plate interior perhaps attributable to bioerosion is present.

Poorly preserved fragments show highly abraded surfaces on which the stumps of larger tubercles can be recognized. The smaller secondary tubercles have been abraded. Plate boundaries exposed by disarticulation as well as surfaces produced by fragmentation can be highly abraded.

Isolated Aristotle's lantern elements are common and mostly consist of hemipyramids and subordinately rotulae and teeth. Epiphyses and compasses also occur sporadically. Fragmentation and abrasion are common (Table 2-Part 1). Spines are mostly fragmented although complete spines do occur, some of which reveal regenerated tips. Well-preserved spines show the base, milled ring collar and striations, which can be partially or totally masked in poorly preserved specimens. Encrustation on echinoid remains, tentatively assigned to coralline algae, is generally low and mostly restricted to spine remains. Isolated plates and spines often show grain indentations, which preserve the outlines of the terrigenous grains often with a smooth cement layer on the surfaces. In some cases, a secondary, calcitic overgrowth within the plates has occurred filling in the pores of the stereom.

Different degrees of fragmentation and abrasion were also observed on mollusk remains. Gastropods consist of complete shells with wellpreserved surface details, some of which retain trace of their original color pattern, and variously sized shell fragments which can be reduced to the columellar pillar. Bivalves show a similar taphonomic gradient from well-preserved and articulated valves to disarticulated and fragmented, highly abraded remains. Mollusk shells show the presence of circular boreholes (Sedilichnus) and bioerosion (Entobia) attributed to clionid sponges.

The remains of the scleractinian coral $C$. caespitosa are preserved as portions of the entire colony to fragments of single branches, which show signs of abrasion, bioerosion and encrustation. Other major biotic constituents are common coralline algae rhodoliths, which range from $2 \mathrm{~cm}$ to $10 \mathrm{~cm}$ maximum length and are dominated by subspherical to ellipsoidal shape, although more flattened examples are also present. Growth forms 

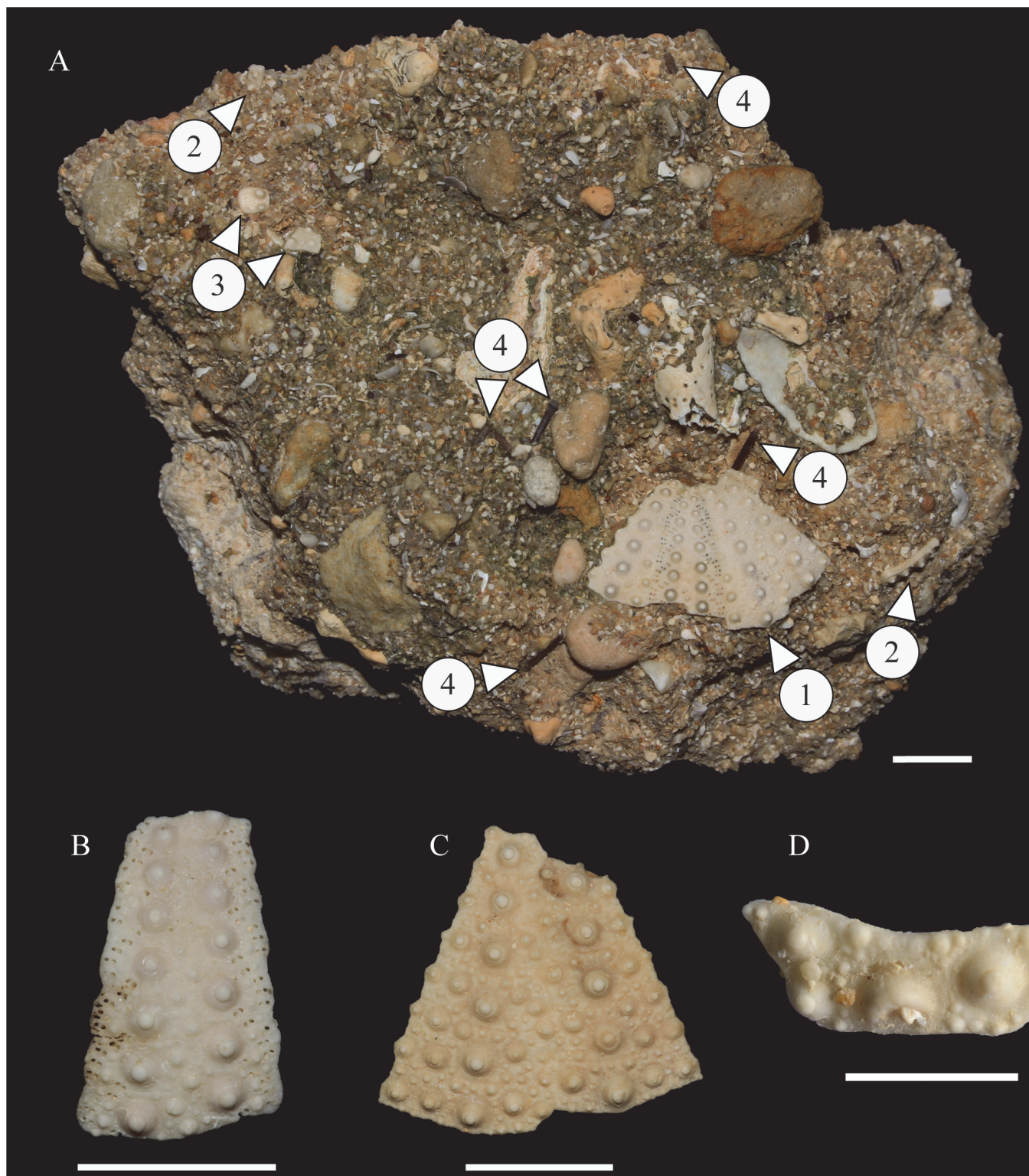

$\mathrm{D}$
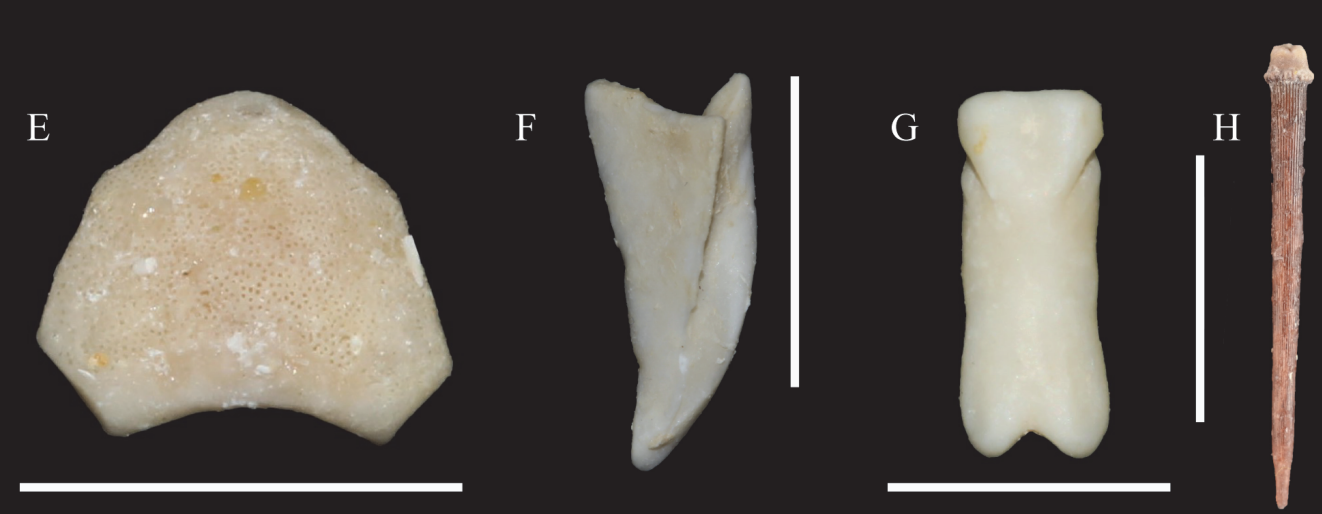

FIGURE 3. Remains of Paracentrotus lividus from Level A of the Is Mesas deposit (Late Pleistocene). A, 1) Fragment of test consisting of ambulacral and interambulacral plates still sutured together and showing interplate fracturing; 2) Isolated plates; 3) Fragments; 4) Spines. B, Large portion of ambulacral column showing intraplate fragmentation. C, Large portion of interambulacral column. D, Fragmented interambulacral plate. E, Madreporite. F, Hemipyramid. G, Rotula. H, Complete spine. A-C, H Scale bars equal $1 \mathrm{~cm}$. E-G Scale bars equal $0.5 \mathrm{~cm}$. 
TABLE 1. Fauna of the Upper Pleistocene deposit of Is Mesas recognized in this study.

\begin{tabular}{|c|c|c|c|c|}
\hline & Taxon & $\begin{array}{l}\text { Habitat-Substrate- } \\
\text { Biocoenosis }\end{array}$ & References & Abbreviations \\
\hline Phylum & Echinodermata & & & SupraL = Supralittoral \\
\hline Class & Echinoidea & & & $\mathrm{L}=$ Littoral \\
\hline Order & Camarodonta & & & $\mathrm{IL}=$ Infralittoral \\
\hline \multirow[t]{3}{*}{ Family } & Parechinidae & & & $\mathrm{ML}=$ Mesolittoral \\
\hline & Paracentrotus lividus & $\mathrm{IL}, \mathrm{H}(\mathrm{PA}), \mathrm{P}$ & $\begin{array}{c}1,2,17, \text { references cited } \\
\text { herein }\end{array}$ & $C L=$ Circalittoral \\
\hline & & & & $\mathrm{SL}=$ Sublittoral \\
\hline Phylum & Mollusca & & & IN = Intertidal \\
\hline Class & Gastropoda & & & $\mathrm{H}=$ Hard substrates \\
\hline Order & $?$ & & & $S=$ Soft sediments \\
\hline \multirow[t]{3}{*}{ Family } & Patellidae & & & $\mathrm{P}=$ Posidonia meadows \\
\hline & Patella caerulea & $\mathrm{IL}, \mathrm{H}(\mathrm{PA})$ & $31,33,34$ & PA = Photophilic algae \\
\hline & Patella rustica & $\mathrm{ML}, \mathrm{IL}, \mathrm{H}(\mathrm{PA})$ & $2,31,33,34$ & $\mathrm{C}=$ Coralligenous \\
\hline Order & Lepetellida & & & SABEL = Sabellaria alveolata reef \\
\hline \multirow[t]{3}{*}{ Family } & Fissurellidae & & & SA = Sciaphilic algae \\
\hline & Diodora gibberula & IL to $\mathrm{CL} H(\mathrm{PA}), \mathrm{P}, \mathrm{C}$ & $17,18,31,33,34$ & $\mathrm{Rh}=$ Rhodolith beds \\
\hline & Diodora graeca & & & \\
\hline Order & Neogastropoda & & & Literature list \\
\hline \multirow[t]{3}{*}{ Family } & Conidae & & & 1) Mortensen, 1943 \\
\hline & Conus ermineus & $\mathrm{L}$ to $\mathrm{SL}, \mathrm{H}, \mathrm{S}$ & 19,28 & 2) Pérès and Picard, 1964 \\
\hline & Conus ventricosus & $\begin{array}{l}\text { IL to } \mathrm{CL}, \mathrm{H} \text { (beneath } \\
\text { boulders, } \mathrm{PA} \text { ), } \mathrm{S}\end{array}$ & $5,11,31,33,34$ & 3) Lipkin and Safriel, 1971 \\
\hline \multirow[t]{2}{*}{ Family } & Columbellidae & & & 4) Conti and Rossini, 1985 \\
\hline & Columbella rustica & $\begin{array}{c}\mathrm{IL}, \mathrm{H} \text { (beneath boulders, } \\
\text { PA), } \mathrm{P}\end{array}$ & $2,5,6,17,27,29,31,33,34$ & 5) Taylor, 1987 \\
\hline \multirow[t]{2}{*}{ Family } & Muricidae & & & 6) Russo et al., 1991 \\
\hline & Hexaplex trunculus & IN, IL to $C L, H(P A), S$ & $5,16,17,33,34$ & 7) Hall-Spencer, 1998 \\
\hline \multirow[t]{2}{*}{ Family } & Pisaniidae & & & 8) Peharda et al., 2002 \\
\hline & Gemophos viverratus & IL, H, S & $12,28,30$ & 9) Rubio and Rolan, 2002 \\
\hline \multirow[t]{2}{*}{ Family } & Nassariidae & & & 10) Russo et al., 2002 \\
\hline & Tritia incrassata & IL, H (PA, SABEL), S, P & $6,11,27,29,40$ & 11) Antoniadou et al., 2005 \\
\hline Order & Trochida & & & 12) Rolán, 2005 \\
\hline \multirow[t]{2}{*}{ Family } & Turbinidae & & & 13) Sivan et al., 2006 \\
\hline & Bolma rugosa & IL to $C L, H(P A, S A), P, C$ & $11,17,18,25,31,33,34,40$ & 14) Spadini, 2006 \\
\hline \multirow[t]{5}{*}{ Family } & Trochidae & & & 15) Trigui El-Menif et al., 2007 \\
\hline & Jujubinus exasperatus & IL to $\mathrm{CL}, \mathrm{H}(\mathrm{PA}), \mathrm{P}, \mathrm{C}$ & $\begin{array}{c}4,6,11,17,18,22,25,27 \\
31,33,34,38,40\end{array}$ & 16) Vasconcelos et al., 2007 \\
\hline & Clanculus jussieui & IL to $C L, P, C$ & 9,14 & 17) Beqiraj et al., 2008 \\
\hline & Clanculus corallinus & IL to $C L, H(P A), P, C$ & $4,11,17,18,31,33,34$ & 18) Casellato and Stefanon, 2008 \\
\hline & Phorcus turbinatus & $\mathrm{ML}, \mathrm{IL}, \mathrm{H}(\mathrm{PA})$ & $2,31,33,34$ & 19) Rosenberg et al., 2009 \\
\hline
\end{tabular}


TABLE 1 (continued).

\begin{tabular}{|c|c|c|c|c|}
\hline & Taxon & $\begin{array}{l}\text { Habitat-Substrate- } \\
\text { Biocoenosis }\end{array}$ & References & Abbreviations \\
\hline Order & Caenogastropoda? & & & 20) Sciberras et al., 2009 \\
\hline \multirow[t]{4}{*}{ Family } & Cerithiidae & & & 21) Rufino et al., 2010 \\
\hline & Cerithium lividulum & IL, H (PA), S & 31,34 & 22) Albano and Sabelli, 2011 \\
\hline & Cerithium vulgatum & IL to $\mathrm{CL}, \mathrm{H}, \mathrm{S}, \mathrm{P}$ & $2,11,17,25,31,33,34$ & 23) Gutierrez-Mas, 2011 \\
\hline & Bittium latreillii & IL to $C L, H(P A, R h), P, C$ & $6,10,11,20,25,38$ & 24) Öztürk, 2011 \\
\hline \multirow[t]{2}{*}{ Family } & Epitoniidae & & & 25) Albano and Sabelli, 2012 \\
\hline & Epitonium clathrus & IL to $\mathrm{CL}, \mathrm{H}(\mathrm{PA}), \mathrm{S}$ & 31,34 & 26) Župan et al., 2012 \\
\hline \multirow[t]{2}{*}{ Family } & Triphoridae & & & 27) Belgacem et al., 2013 \\
\hline & Triphoridae ind. & & & 28) Sessa et al., 2013 \\
\hline Order & Littorinimorpha & & & 29) Urra et al., 2013 \\
\hline \multirow[t]{2}{*}{ Family } & Triviidae & & & 30) Brunetti and Della Bella, 2014 \\
\hline & Trivia arctica & IL to $C L$ & 31,33 & 31) Öztürk et al., 2014 \\
\hline \multirow[t]{2}{*}{ Family } & Littorinidae & & & 32) Pitacco et al., 2014 \\
\hline & Melarhaphe neritoides & SupraL to IL, H (PA) & $2,3,5,31,33,34$ & 33) Alf and Haszprunar, 2015 \\
\hline Class & Bivalvia & & & 34) Poursanidis et al., 2016 \\
\hline Order & Arcida & & & 35) Chimienti et al., 2017 \\
\hline \multirow[t]{2}{*}{ Family } & Arcidae & & & 36) Kersting et al., 2017 \\
\hline & Arca noae & $\begin{array}{c}\text { IL to } C L, H(P A, S A B E L \\
S A), P\end{array}$ & $\begin{array}{c}8,17,18,26,27,31,33,34 \\
40\end{array}$ & 37) Morton and Puljas, 2017 \\
\hline \multirow[t]{2}{*}{ Family } & Glycymerididae & & & 38) Donnarumma et al., 2018 \\
\hline & Glycymeris nummaria & IL to $\mathrm{CL}, \mathrm{S}$ & $2,13,23$ & 39) Giacobbe and Renda, 2018 \\
\hline \multirow[t]{2}{*}{ Family } & Noetiidae & & & 40) Casoli et al., 2019 \\
\hline & Striarca lactea & $\mathrm{IL}, \mathrm{H}, \mathrm{P}, \mathrm{C}$ & $15,22,25$ & \\
\hline Order & Cardiida & & & \\
\hline \multirow[t]{2}{*}{ Family } & Cardiidae & & & \\
\hline & Acanthocardia tuberculata & IL to $C L, S$ (SFBC), $P$ & $2,8,11,17,31,33,34$ & \\
\hline Order & Carditida & & & \\
\hline \multirow[t]{2}{*}{ Family } & Carditidae & & & \\
\hline & Cardita calyculata & $M L, I L, H(P A), S, P$ & $2,27,29,31,33,34$ & \\
\hline Order & Venerida & & & \\
\hline \multirow[t]{4}{*}{ Family } & Veneridae & & & \\
\hline & Irus irus & $\begin{array}{l}\mathrm{ML}, \mathrm{IL} \text { to } \mathrm{CL}, \mathrm{H} \text { (PA, } \\
\text { SABEL), C, S, P }\end{array}$ & $2,11,27,31,33,40$ & \\
\hline & Venerupis geographica & IL, P & 29 & \\
\hline & Clausinella fasciata & IL, S & $7,21,33$ & \\
\hline Order & Lucinida & & & \\
\hline \multirow[t]{3}{*}{ Family } & Lucinidae & & & \\
\hline & Lucinella divaricata & IL to $C L, S, P$ & $11,21,35,38$ & \\
\hline & Ctena decussata & IL, P, S & $35,38,39$ & \\
\hline Order & Ostreida & & & \\
\hline Family & Ostreidae & & & \\
\hline & Ostrea sp. & & & \\
\hline
\end{tabular}


TABLE 1 (continued).

\begin{tabular}{|c|c|c|c|c|}
\hline & Taxon & $\begin{array}{l}\text { Habitat-Substrate- } \\
\text { Biocoenosis }\end{array}$ & References & Abbreviations \\
\hline Order & Mytilida & & & \\
\hline \multirow[t]{2}{*}{ Family } & Mytilidae & & & \\
\hline & Mytilaster minimus & ML, IL, H, (PA), C & $2,18,31,33,34,37,40$ & \\
\hline Order & Pectinida & & & \\
\hline \multirow[t]{2}{*}{ Family } & Anomiidae & & & \\
\hline & Anomia ephippium & IL, P & 29 & \\
\hline Class & Scaphopoda & & & \\
\hline Order & Dentaliida & & & \\
\hline \multirow[t]{3}{*}{ Family } & Dentaliidae & & & \\
\hline & Antalis vulgaris & IL to $C L, S, P, C$ & $2,17,24,25,31,33,34$ & \\
\hline & Antalis inaequicosta & IL to $C L, H(C), S, P$ & $17,24,31$ & \\
\hline Phylum & Cnidaria & & & \\
\hline Class & Anthozoa & & & \\
\hline Order & Scleractinia & & & \\
\hline \multirow[t]{2}{*}{ Family } & Scleractinia incertae sedis & & & \\
\hline & Cladocora caespitosa & $L$ to shallow $S L, H, S, P$ & $17,32,36$ & \\
\hline
\end{tabular}

are dominated by the presence of encrusting thalli and low protuberances.

\section{Recent Paracentrotus lividus Remains}

In Sa Mesa Longa Beach (Figure 6A) remains of Paracentrotus occur abundantly on and within the sediments, around rocky bottoms on which living specimens commonly occur (Figure 6B-H). Other echinoids are represented by very rare remains of the regular echinoid Arbacia lixula (Figure 6I) along with highly abundant tests of the minute clypeasteroid echinoid Echinocyamus pusillus (Figure 6J).

The remains of Paracentrotus from Sa Mesa Longa Beach occur in a broad spectrum of preservation (Table 2-Part 2 and 3; Figure 6B-H) similar to that of the studied fossil counterparts. They mainly consist of isolated coronal elements, most of which belonging to ambulacral and interambulacral plates (see Table 2-Part 2 and 3). Fragments consisting of several plates still sutured together are also frequent. Genital and ocular plates of the apical system were also collected, but are relatively rare. Additionally, complete specimens lack spines, the apical system and the Aristotle's lantern. Fragmented remains representing large parts of the test are present, though rare. Intraplate fragmentation along with surface abrasion occur very commonly (see Table 2-Part 2 and 3). Both complete denuded specimens and test fragments show encrustation by polychaete serpulids, including the genus Spirorbis and coralline algae (Figure 6B-E).

Numerous disarticulated elements of the Aristotle's lantern were recovered and include mostly hemipyramids and subordinately rotulae and teeth. Epiphyses and compasses also occur sporadically. Lantern elements are commonly affected by fragmentation and abrasion while encrustation is low and restricted to hemipyramids and teeth. Spines also abundantly occur. Their state of preservation is also similar to those in the fossil deposits ranging from pristine and complete, which were rarely found, to fragmentary and abraded. Some specimens show regenerated tips. Spine remains also show encrustation by coralline algae.

The very rarely encountered remains of Arbacia lixula consist exclusively of test fragments and isolated plates. The preservation of clypeasteroid Echinocyamus pusillus ranges from complete pristine specimens to fragmented and abraded ones.

\section{Morphology, Test Thickness and Plate Sutures of Paracentrotus lividus}

The test of Paracentrotus is moderately thick with thickness decreasing slightly from near the apex to the ambitus. The ambulacral plates are usually thicker than adjoining interambulacral plates at the ambitus. Both ambulacral and interambulacral plates are thicker at their margins. The extent of plate thickening is greater along the radial 


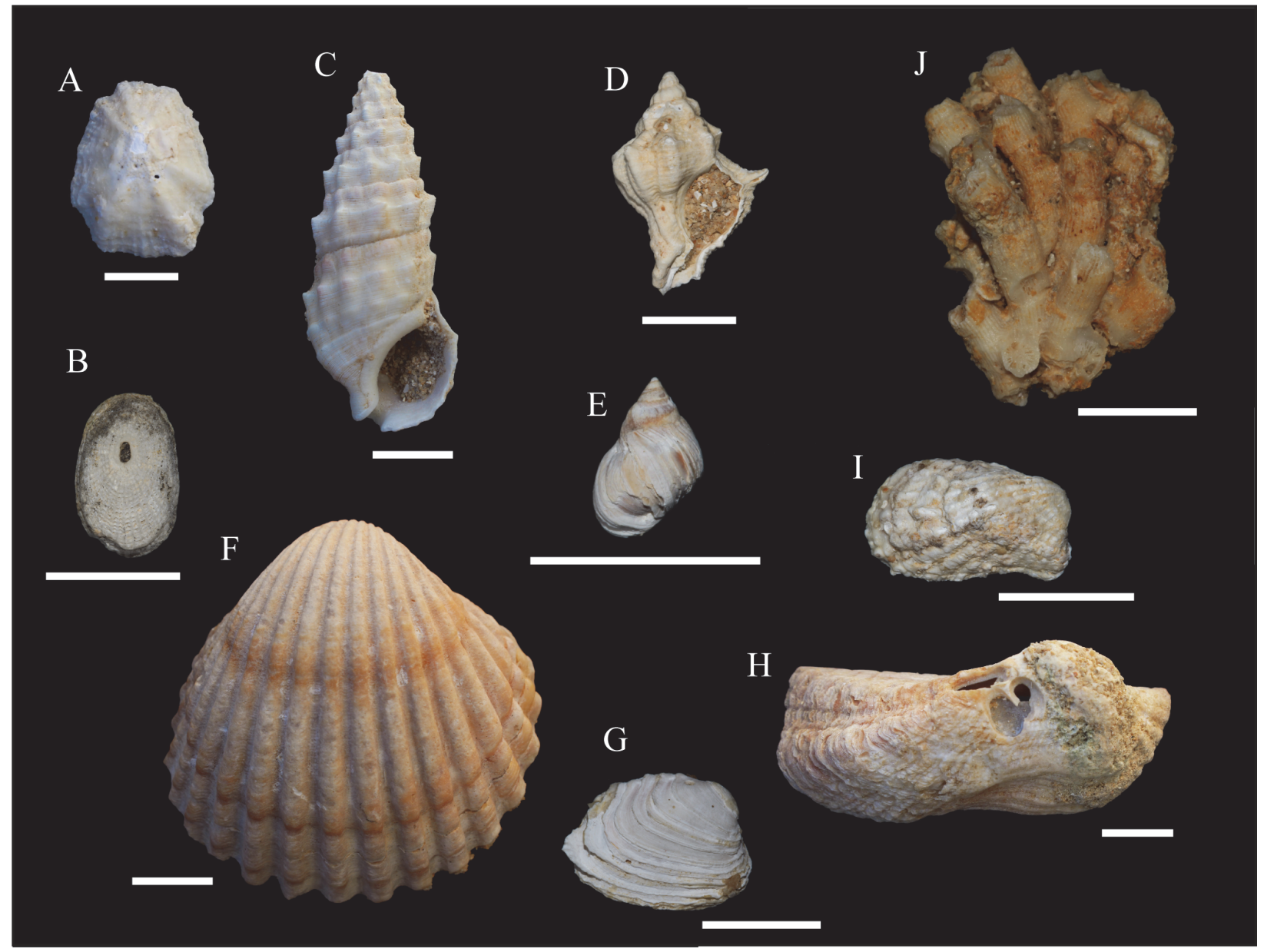

FIGURE 4. Associated fauna from levels A and B of the Is Mesas deposit (Late Pleistocene). A, Patella caerulea. B, Diodora gibberula. C, Cerithium vulgatum. D, Hexaplex trunculus. E, Melarhaphe neritoides. F, Acanthocardia tuberculata. G, Irus irus. H, Arca noae. I, Cardita calyculata. J, Cladocora caespitosa. Scale bars equal $1 \mathrm{~cm}$.

sutures, particularly along the perradial sutures between ambulacral plates, which form a radial ridge when viewed from inside the test. The peristomial margin is thick with the perignathic girdle forming a reinforcing palisade just inside the peristomial edge. Plates are interconnected along sutures by collagenous fibers, crossing plate boundaries. Galleried stereom (sensu Smith, 1980) occurs at the sutures between interambulacral plates (Figure 7). This stereom, which possesses long parallel galleries running in one direction only and shows no pore alignment perpendicular to this direction, is functionally associated with long bundles of collagen fibers at the sutures (Smith, 1980).

In Paracentrotus, parallel galleries can be observed along interradial and adradial sutures between interambulacral plates (aboral to oral direction) (Figure 7A-B) whereas no pore alignment can be observed along latitudinal sutures in interambulacral plates (Figure 7C). In ambulacral plates, galleried stereom can be observed along the adoral sutures joining ambulacral and interambulacral plates, along the adradial sutures, as well as along the perradial suture joining ambulacral plates together (Figure 7D). Additionally, knob-like trabecular protrusions interlock with cavities formed by the opposing plate's stereom thus interlocking the adjacent plates (Figure 7C). This occurs for both radial (longitudinal) sutures (adradial, interradial and perradial) and circumferential (latitudinal) sutures (adapical and adoral).

\section{DISCUSSION}

\section{Paleoenvironmental and Paleoecological Reconstruction}

Geological context, fossil content, including fauna and flora, and sedimentological and taphonomic features indicate a littoral environment with a bathymetric range compatible with the intertidal 

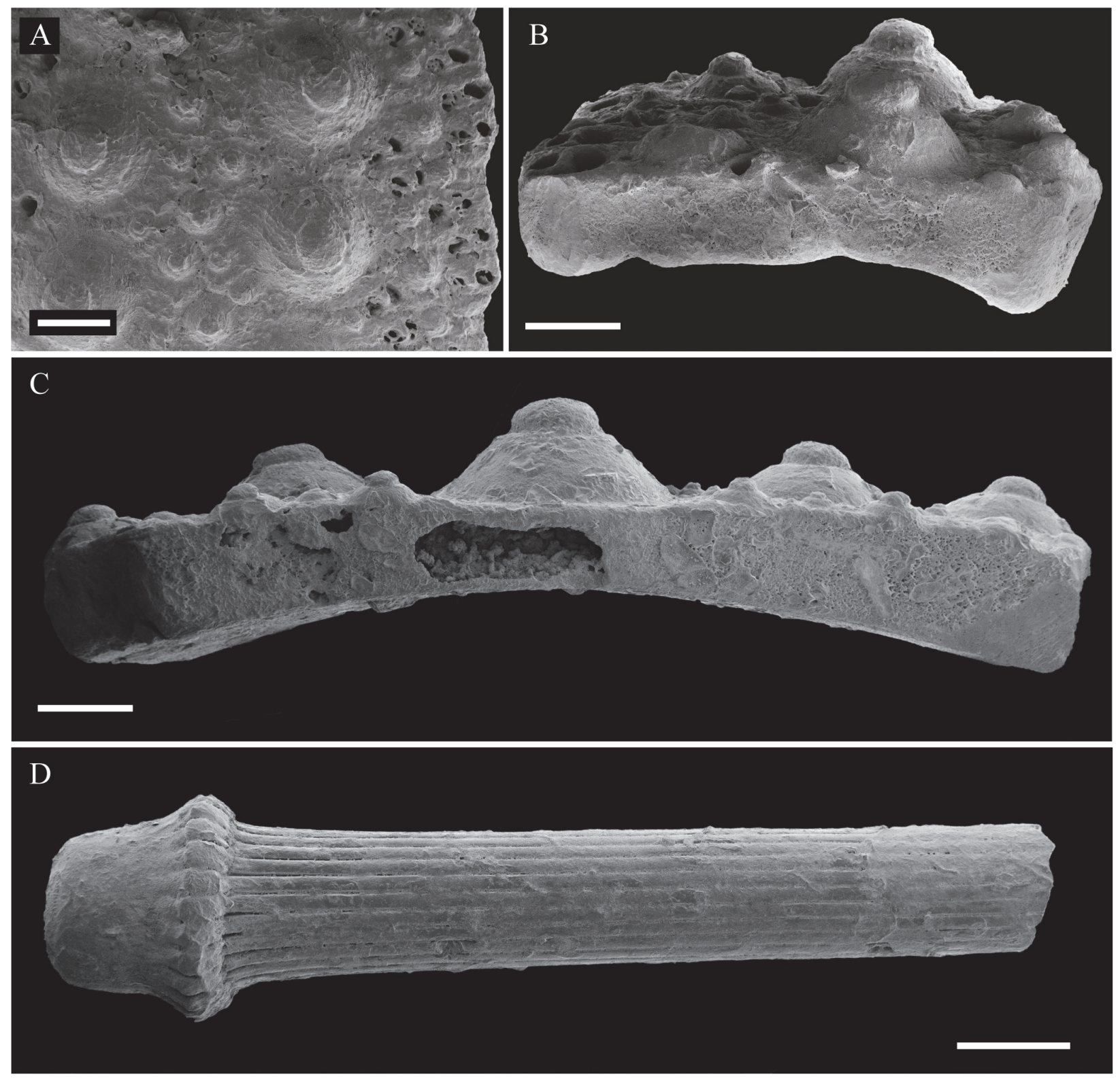

FIGURE 5. Scanning electron micrographs of Paracentrotus remains from Is Mesas. A, Details of an ambulacral column affected by abrasion. B, Two ambulacral plates still sutured together. C, Interambulacral plate showing a cavity possibly related to bioerosion. D, Spine fragment showing fine surface details such as the crenulated milled ring and shaft striation. Scale bars equal $1 \mathrm{~mm}$.

to upper infralittoral zones. This reconstruction is consistent with the paleoecological interpretation of Spano (1993a, b), which was largely based on the study of the mollusk fauna.

This interpretation is consistent with the recent distribution of Paracentrotus lividus, which is common on firm substrates, such as gently sloping rocky walls or loose boulders, and from areas of high hydrodynamic energy in the first meters of exposed shores to calmer waters in bays, lagoon or deeper zones (Régis, 1979; Lozano et al., 1995;
Fernandez and Boudouresque, 1997; Fernandez et al., 2003; Zavodnick, 2003; Bonaviri et al., 2005; Ceccherelli et al., 2007; Fernandez et al., 2012). Paracentrotus lividus also occurs in seagrass meadows such as Posidonia oceanica and Zostera marina, while it is uncommon in meadows of Cymodocea nodosa (Boudouresque and Verlaque, 2020 and references cited therein). It is found also on colonies of Cladocora caespitosa (see Koukouras et al., 1998; Pitacco et al., 2014), an endemic coral living throughout the Mediterranean 
TABLE 2. Occurrence, relative abundance and taphonomy of Paracentrotus lividus remains from Late Pleistocene (Part 1) and recent environments (Part 2 and 3 ). Fragmentation refers to intraplate fracturing. $B=$ spine fragments retaining the base, $T=$ retaining the tip, $S=$ missing both the base and tip.

Part 1.

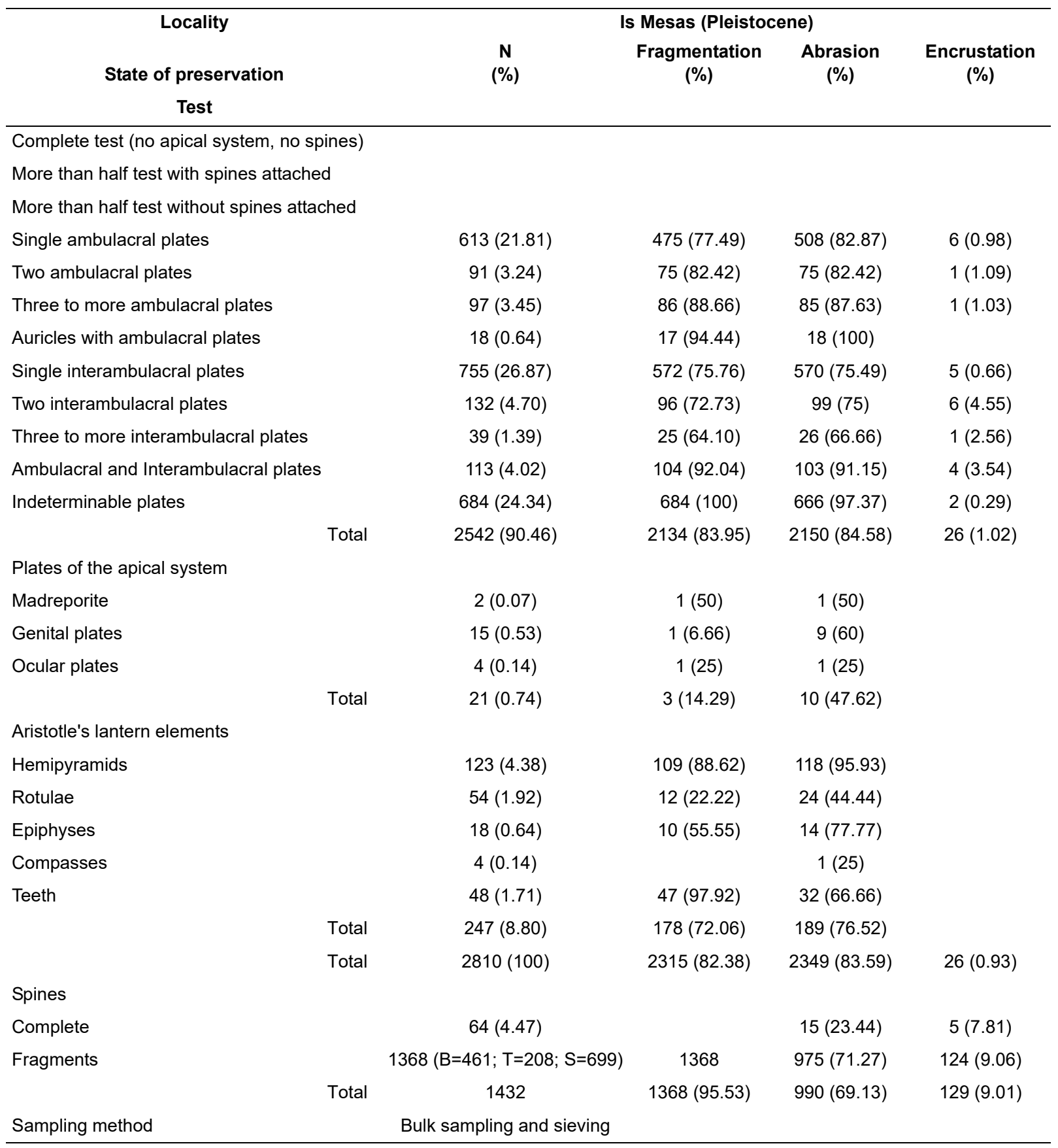

on rocky and sandy bottoms where it can form extensive populations (Kersting et al., 2017; Zunino et al., 2018). Paracentrotus lividus is uncommon on soft substrata, such as sandy and detritic bottoms (Zavodnik 1980, 2003), although in coastal lagoons it can live on coarse sands or even on muddy sediments (Fernandez et al., 2003; Boudouresque and Verlaque, 2020).

Individuals in shallower water under very exposed conditions and/or in intertidal rock pools, resist dislodgment by waves by boring into the hard substratum (e.g., sandstone, limestone, granite), creating cup-shaped cavities where they live per- 
TABLE 2 (continued).

\section{Part 2.}

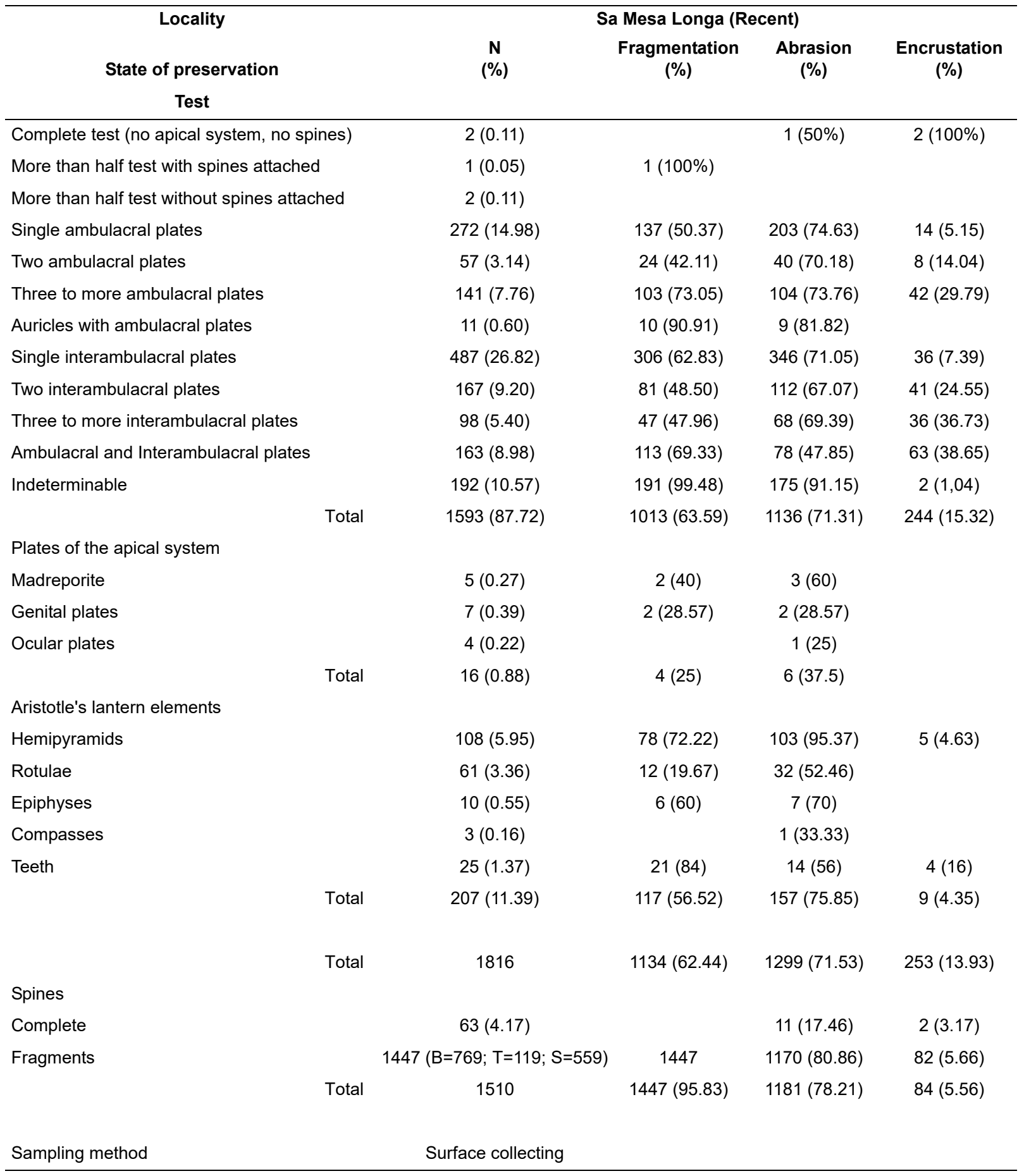

manently or temporarily (Mortensen, 1943; Jacinto and Cruz, 2012). High population densities, up to hundreds of specimens, usually occur in shallow habitats, on gently sloping rocks, pebbles or boulders, in intertidal rocky pools and lagoons (Bonaviri et al., 2005; Fernandez et al., 2012; Ouréns et al., 2014; Boudouresque and Verlaque, 2020).
The identified fauna (Table 1) allows a highly structured environment with rocky substrates and sandy substrates with loose boulders and pebbles and secondary hardgrounds, including coralline algal rhodoliths to be inferred. Patches of Posidonia oceanica possibly occurred as indicated by the presence of numerous gastropod species that 
TABLE 2 (continued).

Part 3

\begin{tabular}{|c|c|c|c|c|c|}
\hline \multicolumn{2}{|l|}{ Locality } & \multicolumn{4}{|c|}{ Sa Mesa Longa (Recent) } \\
\hline \multirow{2}{*}{\multicolumn{2}{|c|}{$\begin{array}{c}\text { State of preservation } \\
\text { Test }\end{array}$}} & $\begin{array}{l}N \\
(\%)\end{array}$ & $\begin{array}{c}\text { Fragmentation } \\
(\%)\end{array}$ & $\begin{array}{c}\text { Abrasion } \\
(\%)\end{array}$ & $\begin{array}{c}\text { Encrustation } \\
(\%)\end{array}$ \\
\hline & & & & & \\
\hline \multicolumn{6}{|c|}{ Complete test (no apical system, no spines) } \\
\hline \multicolumn{6}{|l|}{ More than half test with spines attached } \\
\hline \multicolumn{6}{|c|}{ More than half test without spines attached } \\
\hline Single ambulacral plates & & $603(23.05)$ & $457(75.79)$ & $585(97.01)$ & $6(0.99)$ \\
\hline Two ambulacral plates & & $38(1.45)$ & $30(78.95)$ & $35(92.11)$ & \\
\hline Three to more ambulacral plates & & $17(0.65)$ & $16(94.12)$ & $16(94.12)$ & $1(5.88)$ \\
\hline Auricles with ambulacral plates & & $3(0.11)$ & $3(100)$ & $3(100)$ & \\
\hline Single interambulacral plates & & $526(20.11)$ & $386(73.38)$ & $506(96.18)$ & $13(2.47)$ \\
\hline Two interambulacral plates & & $30(1.15)$ & $23(76.67)$ & $29(96.67)$ & $4(13.33)$ \\
\hline Three to more interambulacral plates & & $15(0.57)$ & $10(66.67)$ & $13(86.67)$ & \\
\hline Ambulacral and Interambulacral plates & & $11(0.42)$ & $9(81.82)$ & $11(100)$ & \\
\hline Indeterminable plates & & $1250(47.79)$ & $1250(100)$ & $1250(100)$ & \\
\hline & Total & $2493(95.30)$ & $2184(87.61)$ & $2448(98.19)$ & $24(0.96)$ \\
\hline \multicolumn{6}{|l|}{ Plates of the apical system } \\
\hline Madreporite & & $2(0.07)$ & $1(50)$ & $2(100)$ & \\
\hline Genital plates & & $14(0.54)$ & $6(42.86)$ & $12(85.71)$ & \\
\hline \multirow[t]{2}{*}{ Ocular plates } & & $4(0.15)$ & & $4(100)$ & \\
\hline & Total & $20(0.76)$ & $7(35)$ & $18(90)$ & \\
\hline \multicolumn{6}{|l|}{ Aristotle's lantern elements } \\
\hline Hemipyramids & & $53(2.03)$ & $53(100)$ & $53(100)$ & \\
\hline Rotulae & & $17(0.65)$ & $3(17.65)$ & $12(70.59)$ & \\
\hline Epiphyses & & $10(0.38)$ & $7(70)$ & $9(90)$ & \\
\hline Compasses & & $3(0.11)$ & $3(100)$ & $1(33.33)$ & \\
\hline \multirow[t]{3}{*}{ Teeth } & & $20(0.77)$ & $20(100)$ & $20(100)$ & \\
\hline & Total & $103(3.94)$ & $86(83.49)$ & $95(92.23)$ & \\
\hline & Total & 2616 & $2277(87.04)$ & $2561(97.90)$ & $24(0.91)$ \\
\hline \multicolumn{6}{|l|}{ Spines } \\
\hline Complete & & $48(3.02)$ & & $26(54.17)$ & \\
\hline \multirow[t]{2}{*}{ Fragments } & & $1542(B=508 ; T=76 ; S=958)$ & 1542 & $1456(94.42)$ & $16(1.03)$ \\
\hline & Total & 1590 & $1542(96.98)$ & $1482(93.21)$ & $16(1.01)$ \\
\hline Sampling method & & Bulk sampling and sieving & & & \\
\hline
\end{tabular}

commonly live in seagrass meadows (Table 1). The fossil material studied herein, including echinoids, mollusks and coral remains, display a wide spectrum of biostratinomic signatures, with respect to fragmentation, encrustation and abrasion that suggests time-averaging in a nearshore environment. The high degree of fragmentation and abrasion of echinoid remains indicates in situ alteration by waves and storms in a littoral environment with high hydrodynamic conditions.

The autochthony/parautochthony of echinoid remains within the Pleistocene deposit is suggested by the size-frequency distribution of some test elements in comparison with recent ones. The size-frequency distribution of the rotulae of the Aristotle's lantern within the fossil deposit is consis- 

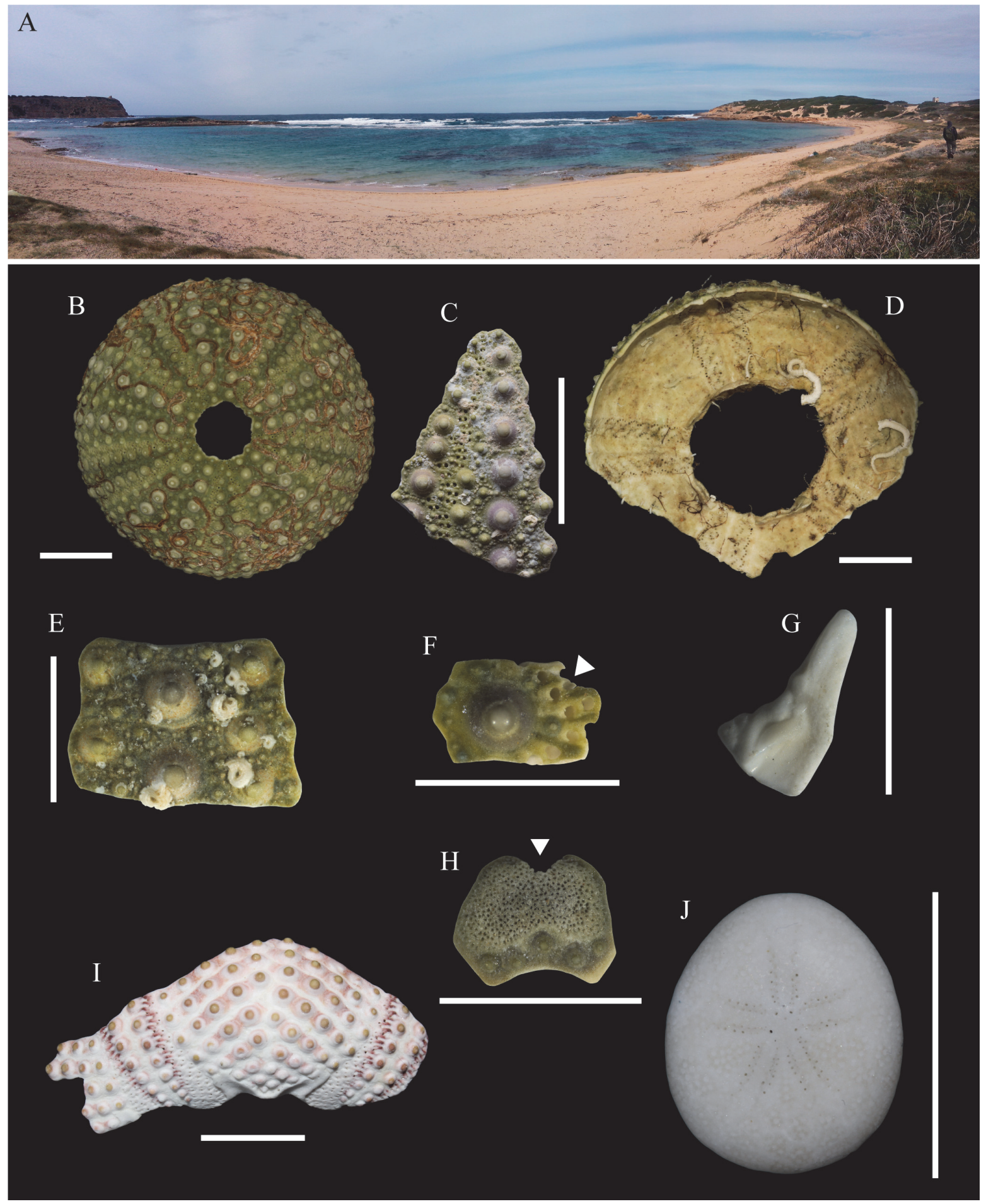

FIGURE 6. A, Panoramic view of Sa Mesa Longa Beach (Central-western Sardinia). B-H, Recent remains of Paracentrotus lividus from Sa Mesa Longa. B, Complete denuded test showing encrustation by serpulids. C, Test fragment made up of several ambulacral and interambulacral plates sutured together, showing inter- and intraplate fragmentation and encrustation by coralline algae and the polychaete Spirorbis. D, Internal view of a large test fragment affected by intraplate fragmentation and encrustation by serpulid worms. E, Two interambulacral plates showing abrasion and encrustation by Spirorbis. F, Single ambulacral plates showing fragmentation (white arrow). G, Epiphysis from the jaw apparatus showing fragmentation and abrasion. $\mathrm{H}$, Madreporite from the apical system affected by fragmentation (white arrow). I, Test fragment of Arbacia lixula showing intraplate fracturing. J, Complete test of Echinocyamus pusillus. B, C, D, I, J Scale bar equals $1 \mathrm{~cm}$. E-H scale bars equal $0.5 \mathrm{~cm}$. 

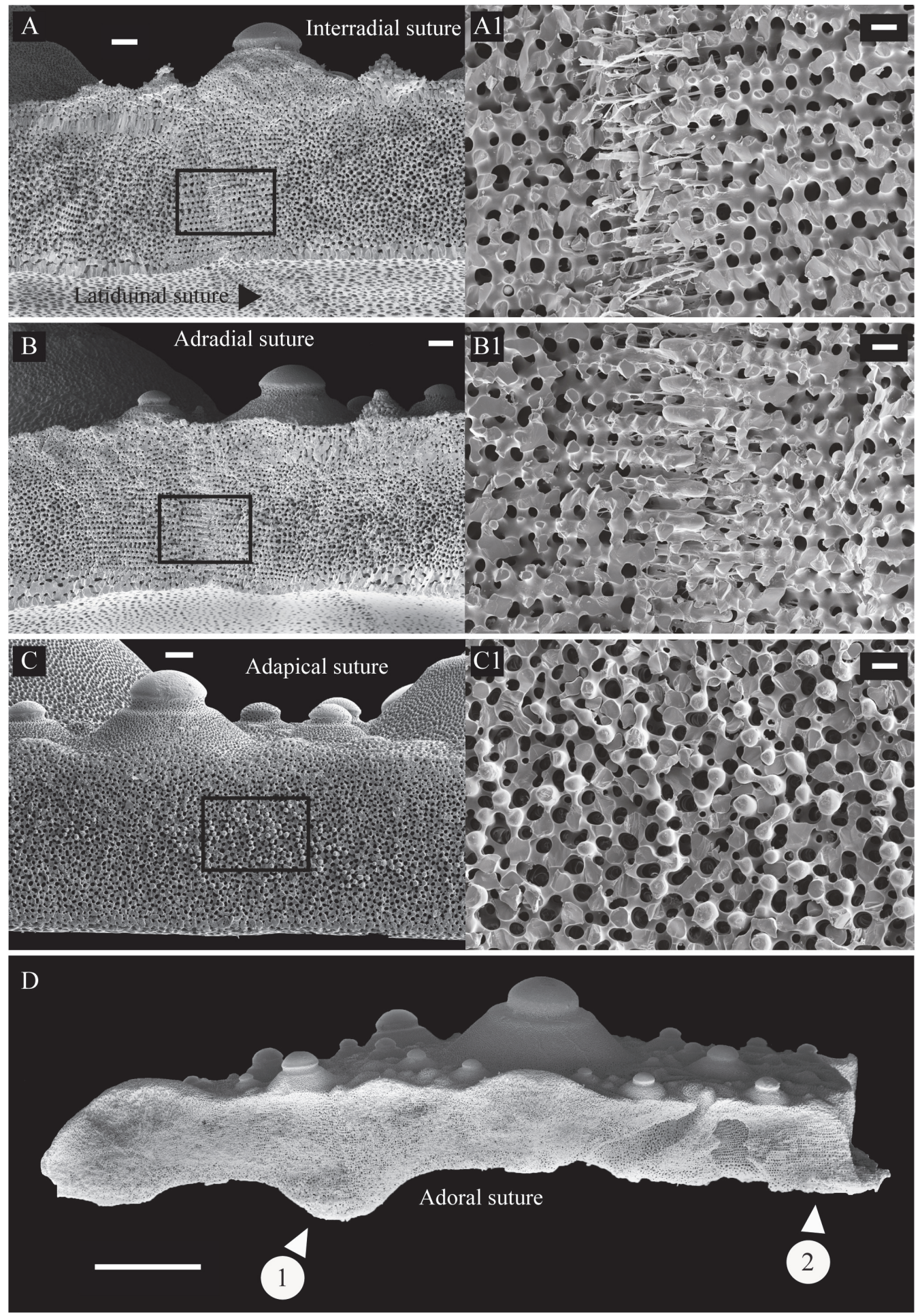

FIGURE 7. Scanning electron micrographs of suture faces in recent Paracentrotus lividus. A, Interradial suture between interambulacral plates showing galleried stereom with galleries running in aboral-oral direction. A1, Detail of the galleried stereom and collagen fibers. B, Adradial suture of interambulacral plates showing galleried stereom. B1, Detail of the parallel galleries and collagen fibers. C, Adapical suture of an interambulacral plates showing knob-like trabecular protrusions and cavities. $\mathrm{C} 1$, The close-up shows numerous knob-like protrusions some of which are interconnected to one another in twos, threes or more. D, Adoral suture of ambulacral plates; 1) Radial ridge at the boundary between ambulacral plates (running across perradial sutures) and 2) galleried stereom. A, B, C Scale bars equal $100 \mu \mathrm{m} ; \mathrm{A} 1, \mathrm{~B} 1, \mathrm{C} 1 \mathrm{Scale}$ bars equal $20 \mu \mathrm{m}$. D Scale bar equals $1 \mathrm{~mm}$. 
tent with that within recent setting (Figure 8) and documents the presence of small to large-sized individuals (ca. 13 to $55 \mathrm{~mm}$ in diameter on the basis of the ratio rotula length/test diameter in recent specimens), which typically co-occur in living population (e.g., Sala and Zabala, 1996; Gianguzza et al., 2006; Addis et al., 2012; Loi et al., 2017). This, along with the lack of sorting, as denoted for example by the presence of both primary and smaller miliary spines, excludes the transport of the echinoid remains over long distances.

\section{Preservation of Paracentrotus lividus}

Fossil remains of Paracentrotus lividus have been recognized before in Pleistocene deposits in the North Atlantic and Mediterranean coastlines (Borghi, 1995, 2003; Borghi et al., 2006; Ferreira Soares et al., 2007; Néraudeau and Masrour, 2008; Madeira et al., 2011). Borghi $(1995,2003)$ and Borghi et al. (2006) reported the occurrence of both the parechinid Paracentrotus lividus and the toxopneustid Sphaerechinus granularis, in Lower Pleistocene sandy deposits of Emilia and Sicily (Italy). These echinoids occur mainly as test fragments and disarticulated spines, although complete, denuded tests were sporadically found. Ferreira Soares et al. (2007) reported the occurrence of Paracentrotus lividus from the Lower/Middle Pleistocene deposits of Portugal. The echinoid remains, which are represented by two test fragments and several spines, occur in association with a mollusk fauna, including Nucella lapillus, Patella vulgata, Littorina littorea and Mytilus edulis, well adapted to living on intertidal and uppermost infralittoral hard substrates with high energy conditions. Néraudeau and Masrour (2008) also document the occurrence of Paracentrotus lividus both from the Pleistocene (Cap Dra) and the Holocene (Rabat) of Marocco.

Paracentrotus lividus also occurs in the Late Pleistocene (MIS 5e) deposits of Santa Maria Island (Azores), in association with Sphaerechinus granularis and the arbacioid Arbacia lixula (Madeira et al., 2011). Paracentrotus and Sphaerechinus were found as test fragments and disarticulated and fragmented spines only. Arbacia lixula occurs as complete tests, numerous test fragments and spines (Madeira et al., 2011). These three sea urchins commonly co-occur in littoral environments on a wide variety of substrates, including rocky bottoms (Sala et al., 1998; Bonaviri et al., 2005; Guidetti and Mori, 2005; Chiantore et al., 2008; Privitera et al., 2008; Agnetta et al., 2015), which is

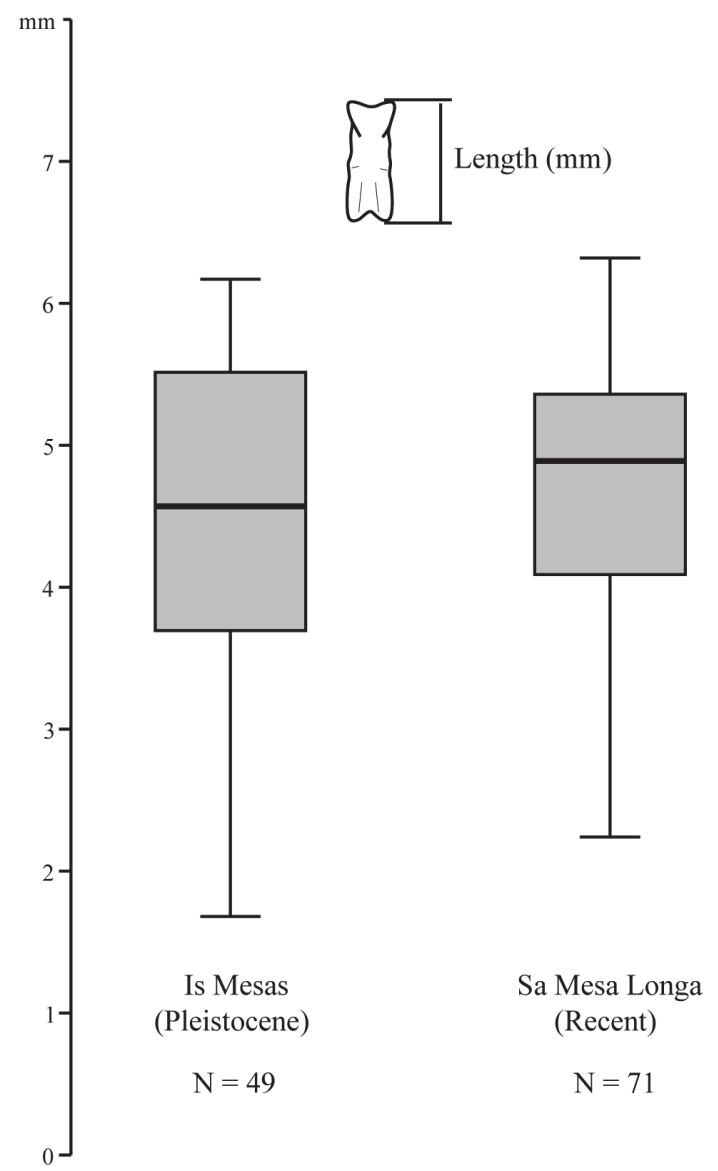

FIGURE 8. Size-frequency distribution of the rotulae of the Aristotle's lantern both in Pleistocene deposit and recent setting. Each box-plot represents 25 and 75 percent quartile of all values, Q1 and Q3 respectively. Black line inside the box represents the median. Whiskers are drawn from Q1 and Q3 to the largest values less than 1.5 times the Interquartile range (Q1-Q3). $\mathrm{N}=$ number of counted specimens.

consistent with the paleoenvironmental setting of the echinoid-bearing deposits of the Late Pleistocene of Santa Maria Island (Ávila et al., 2009).

Observations reported herein document that skeletal remains of Paracentrotus lividus occur abundantly both in Pleistocene deposit and recent environments, displaying a generally high test stability in shallow water in a high energy setting. The relative abundance of these remains (Table 2 and Figure 9) is dependent on factors such as the number of skeletal elements per organism (Table 3), differences in preservation potential of the elements and sampling methods.

A taphonomic bias in the relative abundance of skeletal elements is recognized as complete tests and large fragments consisting of more than half the test are rare and only occur on the sedi- 
A

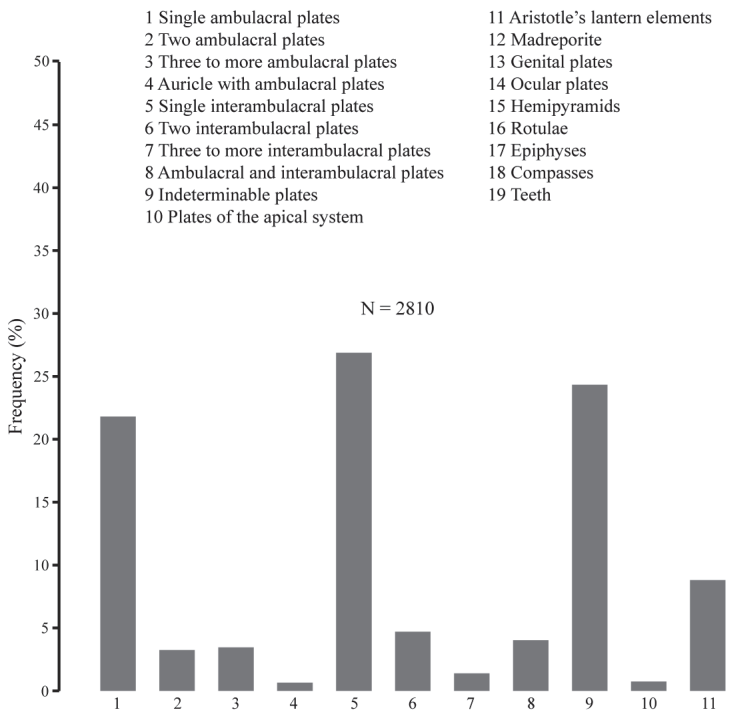

$\mathrm{B}$

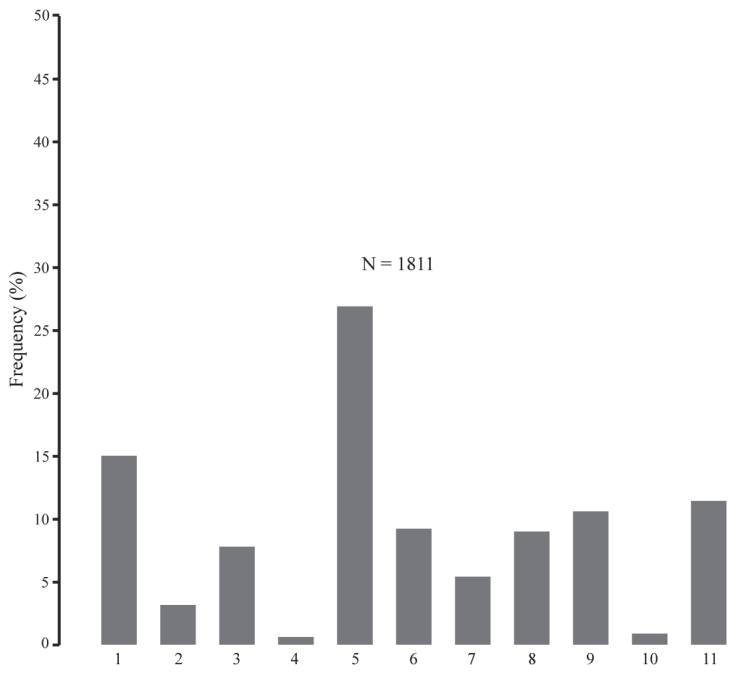

$\mathrm{C}$

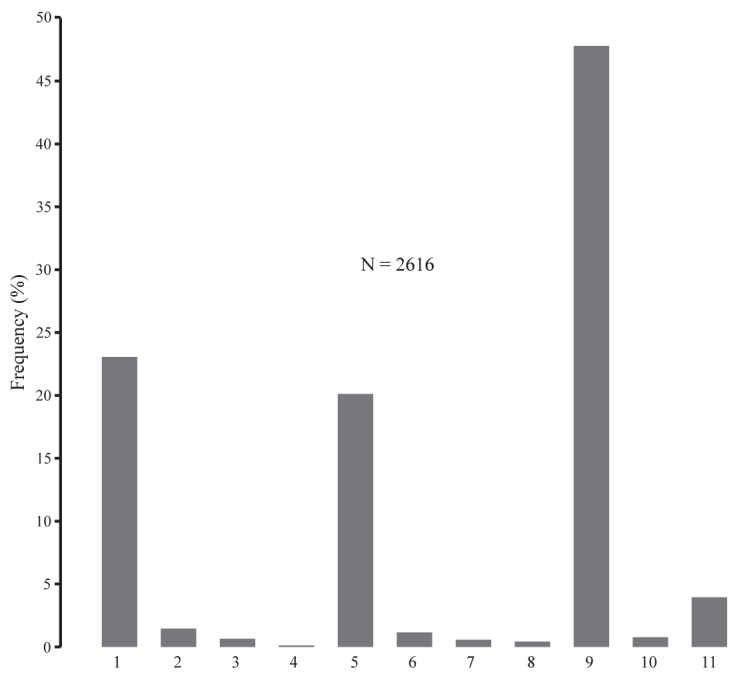

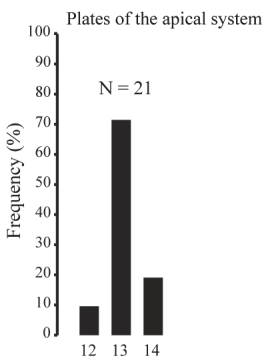
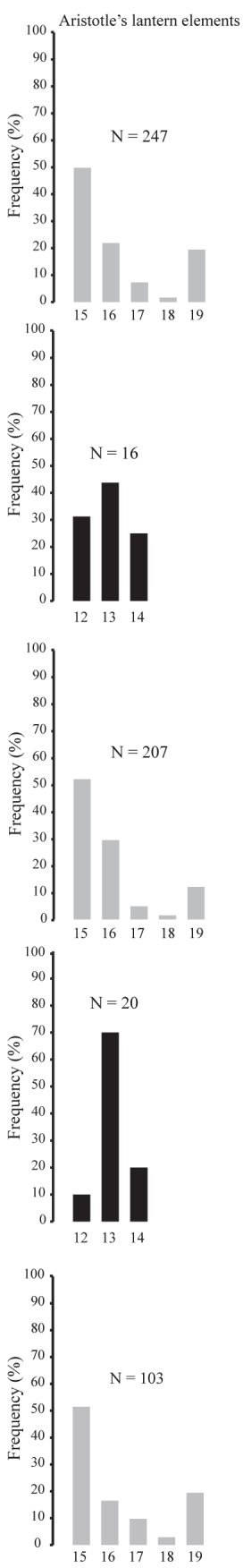

FIGURE 9. Relative abundance of Paracentrotus lividus test remains. A, Is Mesas (Pleistocene-Bulk sample). B, Sa Mesa Longa Beach (Recent-Surface collection). C, Sa Mesa Longa Beach (Bulk sample). N = number of counted specimens. 
TABLE 3. Relative abundance of test elements of Paracentrotus lividus with respect to element abundance in a recent specimen $45.02 \mathrm{~mm}$ in diameter. $\mathrm{E}=$ number of elements. $\mathrm{EA}=$ Expected element abundance $(\mathrm{E} / \mathrm{Total})$. OA $=$ Observed element abundance (E/Total).

\begin{tabular}{|c|c|c|c|c|c|c|c|c|c|c|c|}
\hline \multirow[t]{2}{*}{ Test elements } & \multirow[b]{2}{*}{$E$} & \multirow[b]{2}{*}{ EA } & \multicolumn{3}{|c|}{ Is Mesas } & \multicolumn{3}{|c|}{ Sa Mesa Longa } & \multicolumn{3}{|c|}{ Sa Mesa Longa } \\
\hline & & & $E$ & OA & OA/EA \% & $E$ & OA & OA/EA \% & $E$ & OA & OA/EA \% \\
\hline Ambulacral plates & 251 & 0.515 & 613 & 0.374 & 72.621 & 272 & 0.277 & 53.786 & 603 & 0.482 & 93.592 \\
\hline Interambulacral plates & 191 & 0.392 & 755 & 0.461 & 117.602 & 487 & 0.496 & 126.530 & 526 & 0.420 & 107.142 \\
\hline Madreporite & 1 & 0.002 & 2 & 0.001 & 50 & 5 & 0.005 & 250 & 2 & 0.001 & 50 \\
\hline Genital plates & 4 & 0.008 & 15 & 0.009 & 112.5 & 7 & 0.007 & 87.5 & 14 & 0.011 & 137.5 \\
\hline Ocular plates & 5 & 0.010 & 4 & 0.002 & 20 & 4 & 0.004 & 40 & 4 & 0.003 & 30 \\
\hline Hemipyramids & 10 & 0.020 & 123 & 0.075 & 375 & 108 & 0.109 & 545 & 53 & 0.042 & 210 \\
\hline Rotulae & 5 & 0.010 & 54 & 0.033 & 330 & 61 & 0.062 & 620 & 17 & 0.013 & 130 \\
\hline Epiphyses & 10 & 0.020 & 18 & 0.011 & 55 & 10 & 0.010 & 50 & 10 & 0.008 & 40 \\
\hline Compasses & 5 & 0.010 & 4 & 0.002 & 20 & 3 & 0.003 & 30 & 3 & 0.002 & 20 \\
\hline Teeth & 5 & 0.010 & 48 & 0.029 & 290 & 25 & 0.025 & 250 & 20 & 0.016 & 160 \\
\hline Total & 487 & & 1636 & & & 982 & & & 1252 & & \\
\hline \multicolumn{3}{|l|}{ Sampling method } & \multicolumn{3}{|c|}{ Bulk sampling and sieving } & \multicolumn{3}{|c|}{ Surface collecting } & \multicolumn{3}{|c|}{ Bulk sampling and sieving } \\
\hline
\end{tabular}

ment surface in the recent setting (Table 2; Figure 9). Smaller test fragments, consisting of several plates still sutured together, are proportionally more abundant on the sediment surface in recent settings (see Table 2). This could be, at least in part, due to the shorter time these remains have undergone reworking, as suggested by the fact that both fragmentation and abrasion are slightly lower for recent remains collected on the surface than within the sediment.

Both in the Pleistocene deposit and in the recent environment, a number of large test fragments with ambulacral and interambulacral plates still sutured together, are frequently altered by abrasion and encrustation (Figure 10). This reveals that, not only the presence and distribution of bundles of collagenous fibers (which quickly decay after the death of the echinoids), but also plate thickness and interlocking across plates sutures by interdigitating knobs, are able to hold plates together long enough until burial. This leads to the high preservation potential of larger fragments even within high energy, shallow water environments.

Although ambulacral plates are slightly more numerous than interambulacral plates in the test of Paracentrotus, single ambulacral plates are less represented than interambulacral plates both in fossil and recent settings (see Table 3 ), at least in the $>2 \mathrm{~mm}$ fraction (Figure 11A). Indeed, most ambulacral plates are preserved in the 1-2 $\mathrm{mm}$ fraction and occur mainly as fragmented remains.
By contrast, interambulacral plates mostly occur in the $>2 \mathrm{~mm}$ fraction (Figure 11B). These results suggest that, beyond discrepancies related to different sampling methods, the underrepresentation of ambulacral plates is related to a lower preservation potential with respect to that of interambulacral plates, likely due to the presence of pore-pairs leaving ambulacral plates more fragile (see Figure $6 \mathrm{~F})$.

This conclusion is corroborated by the analysis of bulk sediment samples from Sa Mesa Longa Beach (Figure 11). In shallow water, high-energy, environments which are conducive to constant post-mortem transportation and reworking, ambulacral plates are more rapidly reduced to sandsized particles (1-2 $\mathrm{mm}$ fraction) than interambulacral plates.

Among the elements of the Aristotle's lantern, hemipyramids are the most abundant and represent more than half of the remains both among fossil and recent lantern elements (Table 3 ). This is interpreted as a result of their robustness that leads to a higher preservation potential than other elements such as epiphyses and compasses, which are fragile and are also more difficult to be recognized as fragments.

Spines remains are the most abundant skeletal elements both in fossil and recent settings. They consist mainly of fragmented remains (Figure 12), affected by abrasion and encrustation (Figure 13), although complete spines showing fine surface details do occur. Among fragmented spines, a 

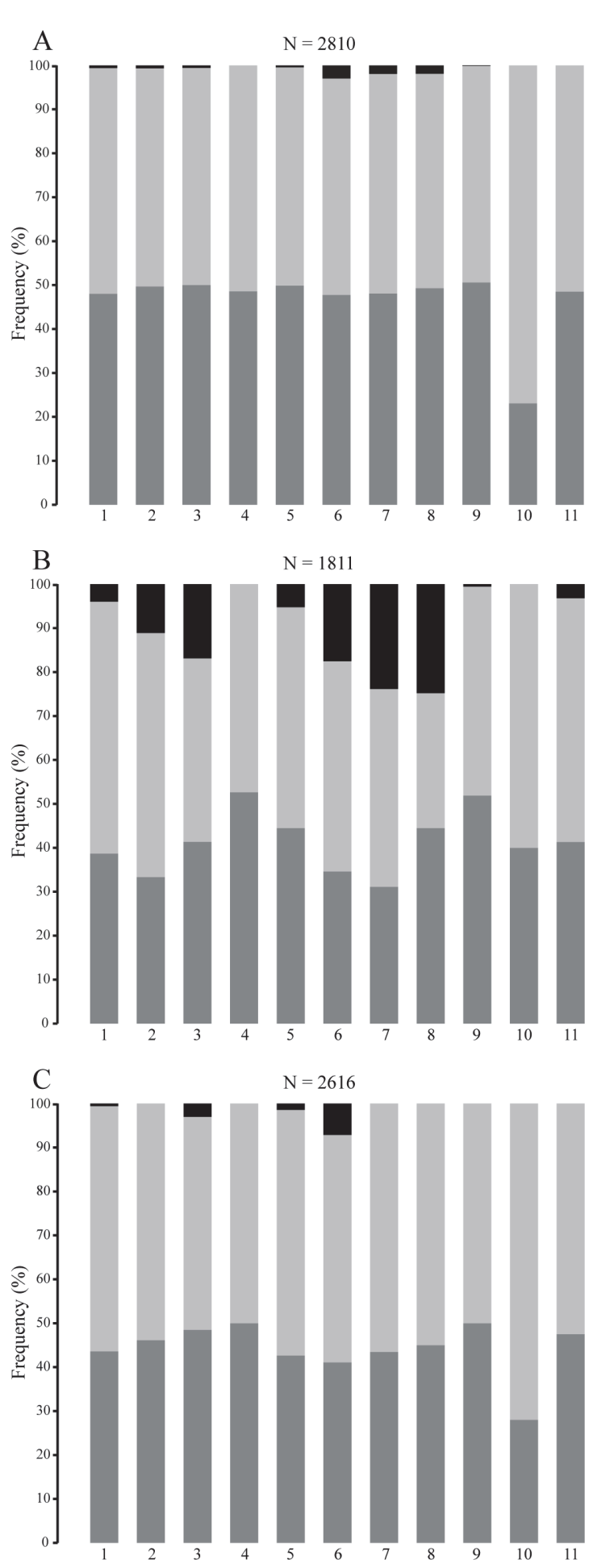

FIGURE 10. Biostratinomic signatures (fragmentation, abrasion and encrustation) of echinoid test remains. A, Is Mesas (Pleistocene-Bulk sample). B, Sa Mesa Longa Beach (Recent-Surface collection). C, Sa Mesa Longa Beach (Recent-Bulk sample). $\mathrm{N}=$ number of counted specimens. Numbers (1-11) are explained in Figure 9. Colors: dark grey, light grey and black represent fragmentation, abrasion and encrustation, respectively. large proportion retain the base while tips are less abundant. This discrepancy is possibly due to the difference in preservation potential, which is higher for the proximal portion of the spines. Spine tips are more fragile and tend to be broken in shallow water environments where echinoid remains are continuously subject to reworking by waves even under fair-weather conditions. In addition, some spines show evidence of regrowth after breakage occurred during life, which often occurs in living specimens as documented by Ebert $(1967,1988)$ for Strongylocentrotus purpuratus and Heterocentrotus mammillatus.

Along with fragmentation by water agitation, predation could be another cause of test breakage and disarticulation as documented by the finding of a recent Paracentrotus test still with spine attached and affected by a large opening (hole) on the aboral side, similar to that documented by Sievers and Nebelsick (2018) for Sphaerechinus granularis. Paracentrotus is commonly preyed by fish, asteroids, crustaceans, gastropods and birds, which can result in fragmentation (Ebling et al., 1966; Sala, 1997; Guidetti, 2004 and references therein; Bonaviri et al., 2010; Boudouresque and Verlaque, 2020).

Although Paracentrotus is common, there is a noticeable lack of Arbacia lixula remains in the Pleistocene deposit studied herein. Arbacia is one of the most common echinoids in shallow water high energy environments of the Mediterranean today and shares the same environment as Paracentrotus. Arbacia lixula also possesses a suite of surface characteristics which allows identification, and is also found, albeit rare, in the census of recent echinoid remains of the present study.

The lack of occurrences of Arbacia in Pleistocene deposits of the Mediterranean area, with the exception of a single well-preserved specimen from the Pleistocene of Livorno (Italy), under the name $A$. pustulosa (Stefanini, 1911), has led to it being regarded as a "post-glacial" invasive species into the Mediterranean Sea (Stefanini, 1911; Mortensen, 1935). More recently, Wangensteen et al. (2012) reported that Arbacia lixula is consistently absent from "Tyrrhenian" deposits and suggested that the expansion in the Mediterranean Sea possibly took place during the last interglacial period (MIS 5e). This is supported by the present study where the rigorous examination of echinoid fragments of Pleistocene sediments also did not reveal the presence of Arbacia.

The scarcity of Echinocyamus remains in the Pleistocene deposit of Is Mesas, is possibly a 

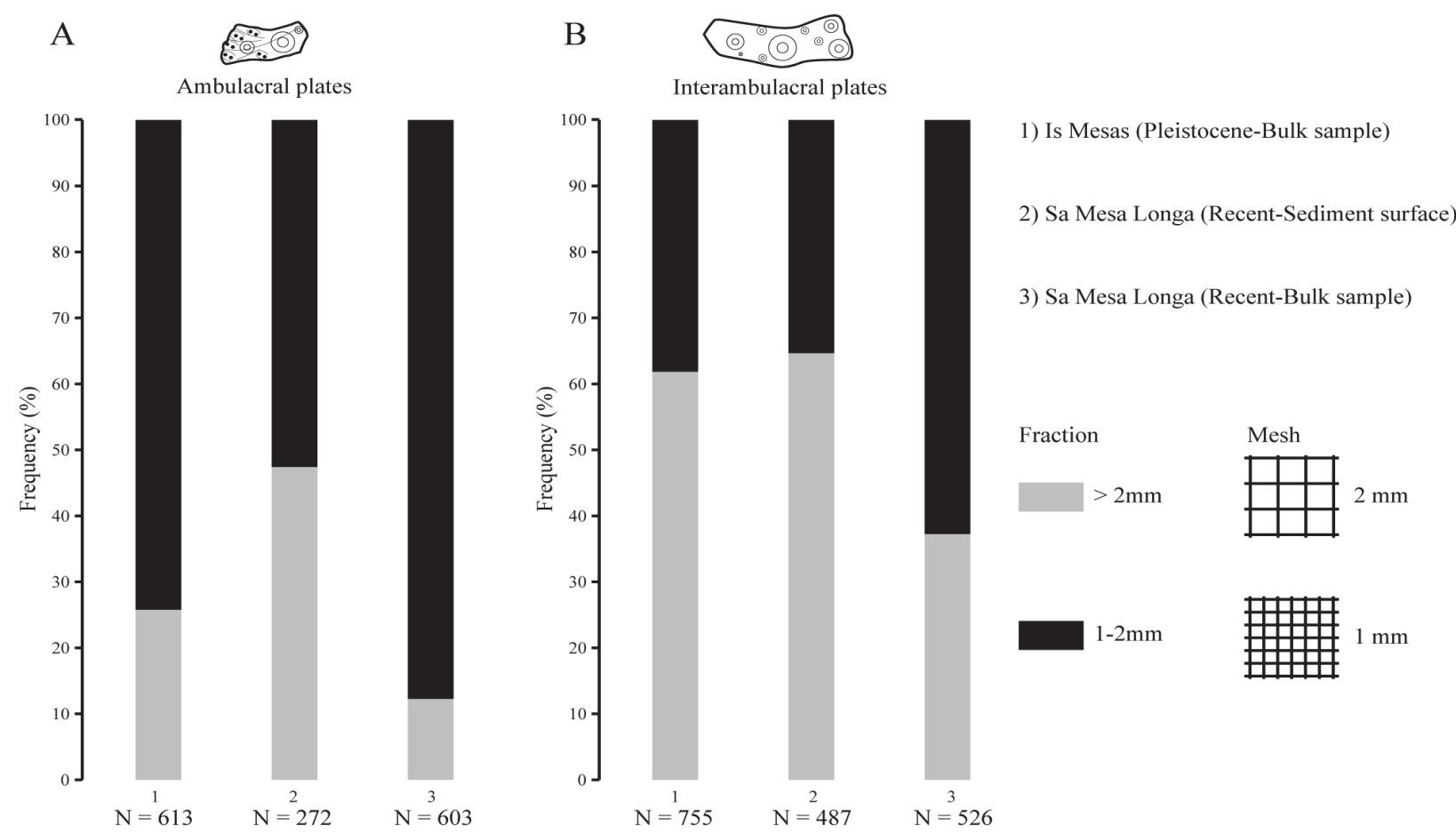

FIGURE 11. Distribution of ambulacral and interambulacral plates in the two sediment fractions ( $>2 \mathrm{~mm}$ and $1-2 \mathrm{~mm}$ ) investigated herein. $\mathrm{N}=$ number of counted specimens.

reflection of a low population density rather than a consequence of the high energy environment destroying all recognizable remnants of this echinoid. Echinocyamus test remains are common in both recent environments (e.g., Grun et al., 2014 and herein) and fossil deposits (e.g., Grun et al., 2017; Mancosu and Nebelsick, 2019), showing high preservation potential due to its skeletal architecture (Grun and Nebelsick, 2018a; Grun et al., 2018b).

\section{Taxonomic Bias}

The relatively poor fossil record of regular echinoids with respect to abundance and diversity over geological time, when compared to that of irregulars, is also the result of sampling methods and taxonomic methodology (Kier, 1977; Greenstein, 1993a). Regular echinoids in general are frequently preserved as fragmented or disarticulated test remains with some exception, generally related to rapid burial (see Mancosu et al., 2015 and references therein). The lack of complete tests generally hampers the identification of regular echinoids at genus and species level. Classification of some groups, such as cidaroids, diadematoids and camarodonts at sub-familial level mainly relies on features, such as pedicellariae, primary spines, apical disc and other test characteristics (Mortensen, 1928; Phelan, 1970; Smith, 1988;
Mooi et al., 2000; Coppard and Campbell, 2004, 2006a, b; Brosseau et al., 2012; Smith and Kroh, 2011), which are often missing in fossils or can only be observed in well-preserved complete tests. Therefore, the classification of fossil regular echinoids at low taxonomic levels based on fragmented material still remains problematic (Mortensen, 1940; Donovan et al., 2001; Kroh, 2005; Borghi and Stara, 2016). Greenstein (1991) states that, in terms of recognizing and identifying fossil echinoids, a size of $2 \mathrm{~mm}$ is a cut-off value since smaller test fragments would possibly not be detected by paleontologists in the field work or unlikely retain features that allow their identification at low taxonomic level.

The possibility of recognizing regular echinoid presence by analyzing fragmented material in fossil deposits has been explored by studies performed on the Pleistocene deposits of shallow water environments (Gordon, 1991; Gordon and Donovan, 1992; Donovan and Gordon, 1993; Donovan and Jones, 1994; Donovan et al., 1994; Borghi, 1995, 2003; Ragaini, 1997; Donovan, 2003, 2005; Borghi et al., 2006; Madeira et al., 2011). Identification of fossil material can be facilitated by direct comparisons with extant representatives (e.g., Gordon and Donovan, 1992; Donovan and Gordon, 1993; Ragaini, 1997). 

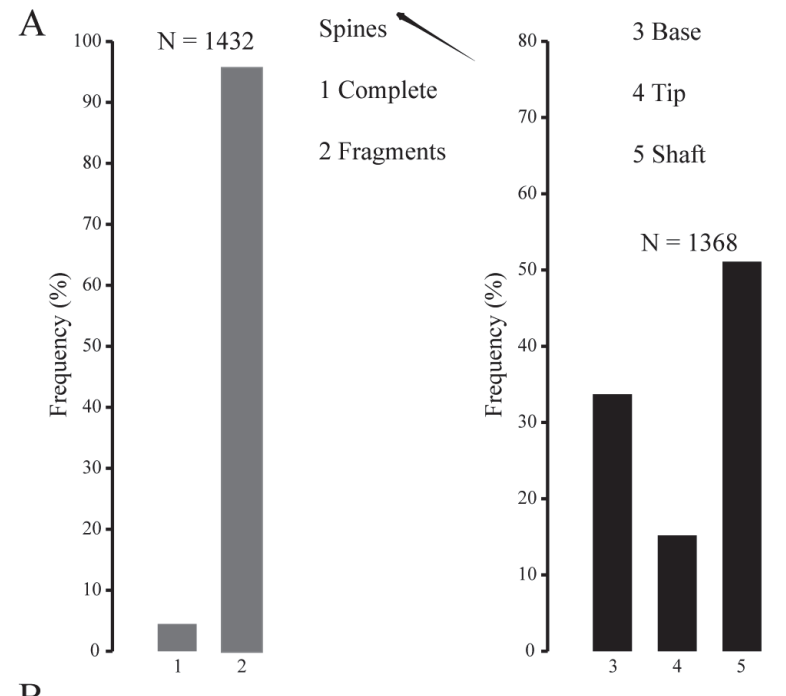

B

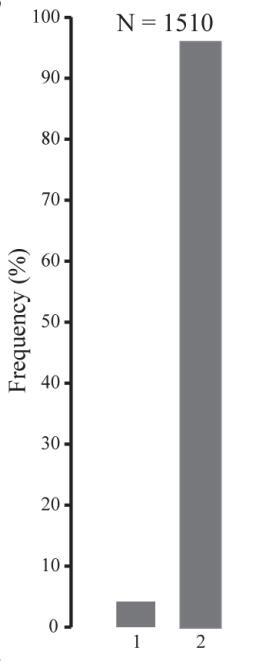

$\mathrm{C}$
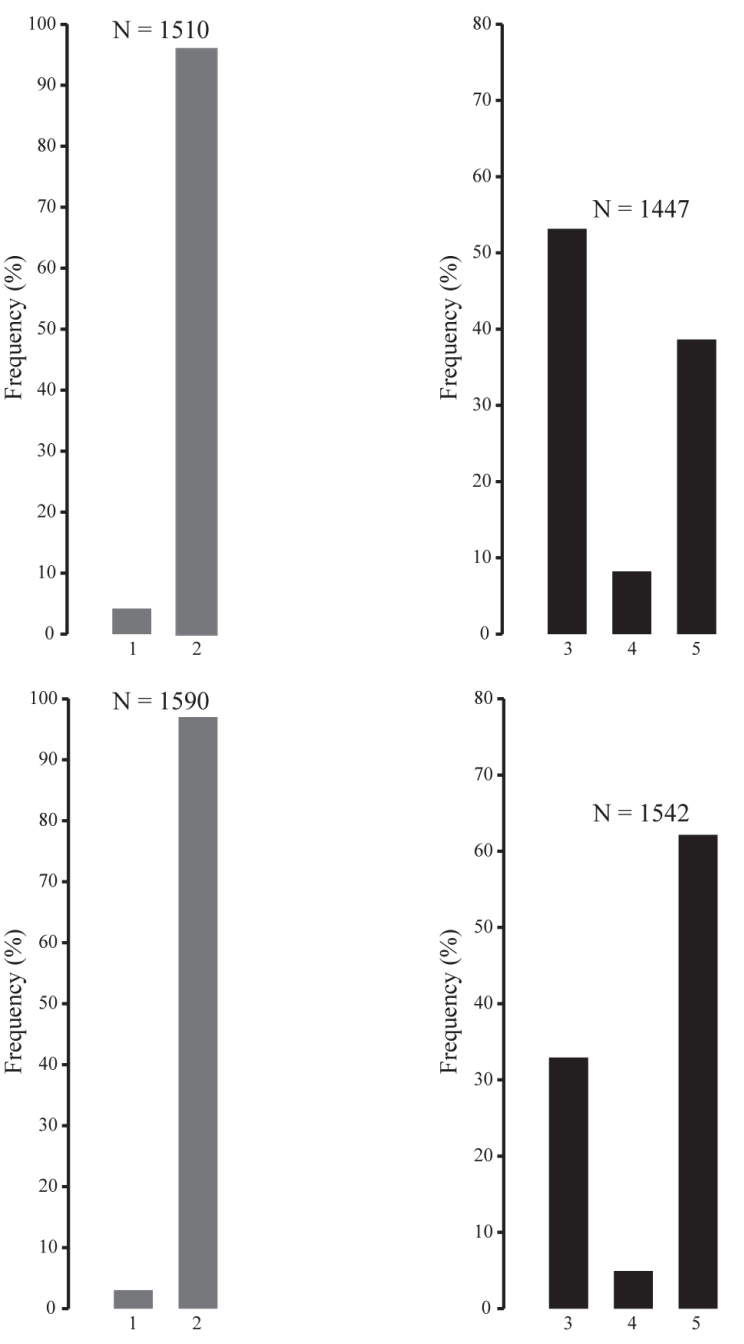

FIGURE 12. Relative abundance of Paracentrotus lividus spine remains. A, Is Mesas (Pleistocene-Bulk sample). B, Sa Mesa Longa Beach (Recent-Surface collection). C, Sa Mesa Longa Beach (Bulk sample). N $=$ number of counted specimens.
Fossil remains of Paracentrotus have been sometimes misidentified as Strongylocentrotus Brandt, 1835 (Mortensen, 1943; Geys and Marquet, 1979) due to the fact that the naked tests of these sea urchins appear very similar in overall morphology. The globiferous pedicellariae and the morphology of the auricles of the perignathic girdle, however, allows these two genera to be distinguished (Mortensen, 1943; Smith and Kroh, 2011). Additionally, in Paracentrotus, the ocular plates in the apical disc are all exert whereas in Strongylocentrotus the posterior oculars (oculars I and V) are generally insert (in adults), in contact with the periproct (Mortensen, 1943; Smith and Kroh, 2011).

The genus Paracentrotus Mortensen, 1903, includes $P$. lividus (Lamarck, 1816) and $P$. gaimardi (Blainville, 1825), which is reported to occur along the coasts of Brazil and West Africa, and inhabits in large number in shallow rocky reefs (Mortensen, 1943; Cordeiro et al., 2014). They differ in the features of the apical plates, which show distinct radiating stripes in $P$. gaimardi and in their pedicellariae (Mortensen, 1943; Smith and Kroh, 2011). Although no pedicellariae have been found in the studied deposits, the occurrence of all test elements, including the auricles, the apical system plates and Aristotle's lantern elements, which themselves are rare finds in the fossil record, allows for the identification as Paracentrotus lividus. Herein, complete and well-preserved test elements occur abundantly both in $>2 \mathrm{~mm}$ and the 1$2 \mathrm{~mm}$ fractions allowing identification of fossil remains at low taxonomic level even in sand particle-size fraction.

\section{CONCLUSIONS}

This study documents the presence of abundant remains of the regular echinoid Paracentrotus lividus in Late Pleistocene (Tarantian, MIS 5e) deposits of Is Mesas (southern Sardinia) and modern shore deposits of Sa Mesa Longa Beach (Central-Western Sardinia). In the Pleistocene deposit the occurrence of Paracentrotus and associated mollusk fauna, including both bivalves and gastropods, allows a shallow water environment with rocky substrate and adjacent coarse-grained soft sediments and possibly sea grass to be inferred. Additionally, patches of coralline-algae rhodoliths and colonies of Cladocora caespitosa occurred. Fauna diversity, taphonomy and sedimentological features point to an autochthonous to parautochthonous assemblage (a within-habitat time averaged assemblage). Echinoid remains include 


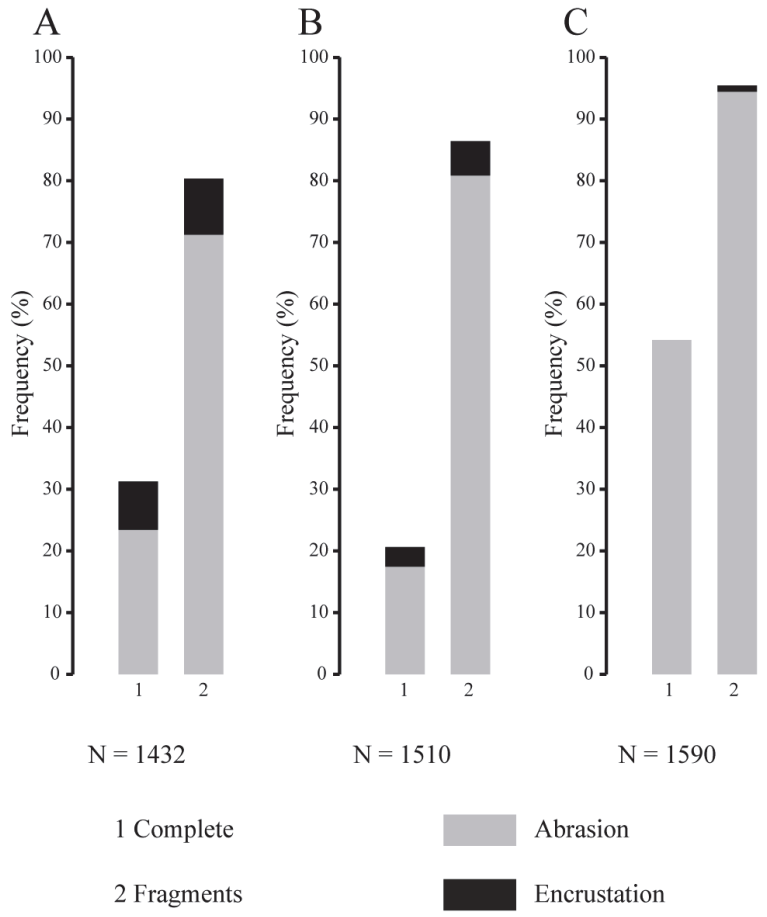

FIGURE 13. Biostratinomic signatures (abrasion and encrustation) of spine remains. A, Is Mesas (Pleistocene-Bulk sample). B, Sa Mesa Longa Beach (RecentSurface collection). C, Sa Mesa Longa Beach (RecentBulk sample). $\mathrm{N}=$ number of counted specimens

variously sized test fragments and isolated ambulacral and interambulacral plates, plates of the apical system, elements of the Aristotle's lantern and complete and fragmented spines. Although no whole echinoid tests were found, Paracentrotus lividus occur as large test fragments depending to its relatively robust test and stereomic interlocking. This interpretation is consistent with observation in recent environments where Paracentrotus remains, which range from complete denuded tests to isolated elements, have been recognized in great abundance on and within the sediments around rocks where living populations occur.

Echinoid remains in the Pleistocene deposit reflect those in recent environment with respect to relative abundance and biostratinomic signatures, and are useful indicators of paleoenvironmental and paleoecological conditions even in shallow water, high-energy environments. This study indicates that when rocky shore facies are preserved in the fossil record the remains of epibenthic regular echinoids may be locally abundant, mostly as disarticulated bioclasts.

Discrepancy in relative abundance among various test elements with respect to the expected skeletal element abundance in complete specimens and their different distribution in size fraction (1-2 $\mathrm{mm}$ and $>2 \mathrm{~mm}$ ) are indicative of differences in preservation potential. Reworking of echinoid remains tends to increase the richness of taphonomically durable elements such as interambulacral plates over ambulacral ones and hemipyramids and rotulae over the other elements of the Aristotle's lantern. Differential resistance of test elements to taphonomic processes potentially led to taxonomic bias.

Besides preservation failure, the fossil record of regular echinoids may be biased by inadequate sampling that hampers identification at low taxonomic levels. Herein, the analysis of fragmented material, allows for the identification of echinoid remains at species level, even at a very coarse sand fraction (1-2 mm), when supported by comparison with extant species. This approach is difficult for other taxonomic groups such as diadematid echinoids, the systematics of which is based on features that are seldom preserved in the fossil record, and other now extinct echinoid taxa which lack comparable recent taxonomic representatives.

\section{ACKNOWLEDGEMENTS}

We thank G.L. Pillola and L. Lecca (Dipartimento di Scienze Chimiche e Geologiche, Università degli Studi di Cagliari) for their help and useful discussions during the preparation of the paper; we also like to thank C.G. Martin (State Museum of Natural History, Stuttgart Germany) for SEM pictures. We are grateful with T. Grun and two anonymous reviewers for their comments and suggestions, which helped to improve the manuscript. 


\section{REFERENCES}

Addis, P., Secci, M., Angioni, A., and Cau, A. 2012. Spatial distribution patterns and population structure of the sea urchin Paracentrotus lividus (Echinodermata: Echinoidea), in the coastal fishery of western Sardinia: a geostatistical analysis. Scientia Marina, 76:733-740. https:// doi.org/10.3989/scimar.03602.26b

Agnetta, D., Badalamenti, F., Ceccherelli, G., Di Trapani, F., Bonaviri, C., and Gianguzza, P. 2015. Role of two co-occurring Mediterranean sea urchins in the formation of barren from Cystoseira canopy. Estuarine, Coastal and Shelf Science, 152:73-77. https://doi.org/10.1016/ j.ecss.2014.11.023

Albano, P.G. and Sabelli, B. 2011. Comparison between death and living molluscs assemblages in a Mediterranean infralittoral off-shore reef. Palaeogeography, Palaeoclimatology, Palaeoecology, 310:206-215. https://doi.org/10.1016/j.palaeo.2011.07.012

Albano, P.G. and Sabelli, B. 2012. The molluscan assemblages inhabiting the leaves and rhizomes of a deep water Posidonia oceanica settlement in the central Tyrrhenian Sea. Scientia Marina, 76:721-732. https://doi.org/10.3989/scimar.03396.02c

Alf, A. and Haszprunar, G. 2015. Mittelmeer-Mollusken. Prosobranchia \& Bivalvia. ConchBooks Verlag, Hackenheim, Germany.

Allison, P.A. 1990. Variation in rates of decay and disarticulation of Echinodermata: implications for the application of actualistic data. Palaios, 5:432-440. https://doi.org/10.2307/3514836

Antoniadou, C., Koutsoubas, D., and Chintiroglou, C.C. 2005. Mollusca fauna from infralittoral hard substrate assemblages in the North Aegean Sea. Belgian Journal of Zoology, 135:119126.

Ávila, S.P., Madeira, P., Zazo, C., Kroh, A., Kirby, M., da Silva, C.M., Cachão, M., and de Frias Martins, A.M. 2009. Palaeocology of the Pleistocene (MIS 5.5) outcrops of Santa Maria Island (Azores) in a complex oceanic tectonic setting. Palaeogeography, Palaeoclimatology, Palaeoecology, 274:18-31. https://doi.org/10.1016/j.palaeo.2008.12.014

Banno, T. 2008. Ecological and taphonomic significance of spatangoid spines: relationship between mode of occurrence and water temperature. Paleontological Research, 12:145-157. https://doi.org/10.2517/1342-8144(2008)12[145:eatsos]2.0.co;2

Barca, S., Melis, E., Annino, E., Cincotti, F., Ulzega, A., Orrù, P., and Pintus, C. 2005. Note Illustrative della Carta Geologica d'Italia alla scala 1:50000, Foglio 557 "Cagliari". Servizio Geologico d'Italia, Regione Autonoma della Sardegna, Società Elaborazioni Cartografiche, Firenze.

Barca, S., Melis, E., and Pistis, M. 2017. Note Illustrative della Carta Geologica d'Italia alla scala 1:50000, Foglio 566 "Pula". Servizio Geologico d'Italia, Regione Autonoma della Sardegna, Società Elaborazioni Cartografiche, Firenze.

Barca, S., Patta, E.D., Murtas, M., Pisanu, G., and Serra, M. 2016. Note Illustrative della Carta Geologica d'Italia alla scala 1:50000, Foglio 528 "Oristano". Servizio Geologico d'Italia, Regione Autonoma della Sardegna, Società Elaborazioni Cartografiche, Firenze.

Barras, C.G. 2008. Morphological innovation associated with the expansion of atelostomate irregular echinoids into fine-grained sediments during the Jurassic. Palaeogeography, Palaeoclimatology, Palaeoecology, 263:44-77. https://doi.org/10.1016/j.palaeo.2008.01.026

Belaústegui, Z., Nebelsick, J.H., de Gibert, J.M., Domènech, R., and Martinell, J. 2012. A taphonomic approach to the genetic interpretation of clypeasteroid accumulations from Tarragona (Miocene, NE Spain). Lethaia, 45:548-565. https://doi.org/10.1111/j.15023931.2012.00314.x

Belgacem, W., Langar, H., Pergent, G., and Ben Hassine, O.K. 2013. Associated mollusc communities of a Posidonia oceanica meadow in Cap Zebib (off North East Tunisia). Aquatic Botany, 104:170-175. https://doi.org/10.1016/j.aquabot.2011.09.012

Beqiraj, S., Kashta, L., Kuçi, M., Kasemi, D., Mato, X., and Gace, A. 2008. Benthic macrofauna of Posidonia oceanica meadows in the Albanian coast. Natura Montenegrina Podgorica, 7:55-69.

Blainville, H.M.D. d. 1825. Oursin, Echinus (Actinozoaires.). Dictionnaire des Sciences Naturelles. F.G. Levrault, Strasbourg and Paris. 
Bonaviri, C., Agnetta, D., Gianguzza, P., Vega Fernández, T., and Riggio, S. 2005. Effetto della complessità strutturale del substrato sulla distribuzione di Paracentrotus lividus e Arbacia lixula nel barren dell'A.M.P. "Isola di Ustica", p. 1-16. Atti on line $15^{\circ}$ Congresso Nazionale Società Italiana Ecologia, Torino.

Bonaviri, C., Pipitone, C., Gianguzza, P., and Hereu, B. 2010. Predation on young Paracentrotus lividus settlers: Implication for Mediterranean rocky infralittoral stability. Biologia Marina Mediterranea, 17:98-101.

Borghi, E. 1995. Paracentrotus lividus (Lamarck, 1816) nel Pleistocene dell'Emilia. Bollettino della Società Reggiana di Scienze Naturali, 15:1-23.

Borghi, E. 2003. Osservazioni su alcuni echinodermi del Plio/Pleistocene dell'Emilia. Parva Naturalia, 2:109-124.

Borghi, E. and Stara, P. 2016. I cidaroidi (Echinoidea) del Miocene Inferiore-Medio dell'EmiliaRomagna e di San Marino. Parva Naturalia, 11:13-45.

Borghi, E., Bajo, I., and Rico, A. 2006. Arbacina romana (Merian, 1858) from the lower Pleistocene of Favignana Island (Sicily). Parva Naturalia, 7:47-71.

Boudouresque, C.F. and Verlaque, M. 2007. Ecology of Paracentrotus lividus. Developmets in Aquaculture and Fisheries Science, 37:243-285. https://doi.org/10.1016/s01679309(07)80077-9

Boudouresque, C.F. and Verlaque, M. 2020. Paracentrotus lividus, p. 447-485. In Lawrence J.M. (ed.), Sea Urchins: Biology and Ecology (4th Edition). Developments in Aquaculture and Fisheries Science Volume 43, Elsevier, Amsterdam. https://doi.org/10.1016/b978-0-12819570-3.00026-3

Brandt, J.F. 1835. Prodromus descriptionis animalium ab H. Mertensio observatorium: fasc. I. Polypos, Acalephas Discophoras et Siphonophoras, nec non Echinodermata continens. Recueil des Actes de l'Academie Imperiel des Sciences, St Petersburg.

Brosseau, O., Murienne, J., Pichon, D., Vidal, N., Eléaume, M., and Ameziane, N. 2012. Phylogeny of Cidaroida (Echinodermata: Echinoidea) based on mitochondrial and nuclear markers. Organisms Diversity and Evolution, 12:155-165. https://doi.org/10.1007/s13127012-0087-1

Brunetti, M.M. and Della Bella, G. 2014. La famiglia Buccinidae Rafinesque, 1815 nel PlioPleistocene italiano: i generi Aplus De Gregorio, 1884, Engina Gray, 1839 e Gemophos Olsson and Harbinson, 1953 (Gastropoda). Bollettino Malacologico, 50:11-32.

Carboni, S. and Lecca, L. 1985. Osservazioni sul Pleistocene Medio-Superiore della Penisola del Sinis (Sardegna Occidentale). Bollettino della Società Geologica Italiana, 104:459-477.

Carboni, S., Lecca, L., Hillaire-Marcel, C., and Ghaleb, B. 2014. MIS 5e at San Giovanni di Sinis (Sardinia, Italy): Stratigraphy, U/Th dating and "eustatic" inferences. Quaternary International, 328-329:21-30. https://doi.org/10.1016/j.quaint.2013.12.052

Casellato, S. and Stefanon, A. 2008. Coralligenous habitat in the northern Adriatic Sea: an overview. Marine Ecology, 29:321-341. https://doi.org/10.1111/j.1439-0485.2008.00236.x

Casoli, E., Bonifazi, A., Ardizzone, G., Gravina, M.F., Russo, G.F., Sandulli, R., and Donnarumma, L. 2019. Comparative analysis of mollusc assemblages from different hard bottom habitats in the central Tyrrhenian Sea. Diversity, 11:74. https://doi.org/10.3390/ d11050074

Ceccherelli, G., Pais, A., Serra, S., Pinna, S., Ruiu, A., and Sechi, N. 2007. The influence of Posidonia oceanica patches on the distribution patterns of Paracentrotus lividus in a Central Western Mediterranean MPA. Biologia Marina Mediterranea, 14:72-73.

Chiantore, M., Vielmini, I., Privitera, D., Mangialajo, L., and Cattaneo-Vietti, R. 2008. Habitat effects on the population structure of Paracentrotus lividus and Arbacia lixula. Chemistry and Ecology, 24:145-157. https://doi.org/10.1080/02757540801965423

Chimienti, G., Montesanto, F., Rotella, B., Panetta, P., De Marco, A., and Mastrototaro, F. 2017. Coastal soft-bottom molluscs at Isole Tremiti MPA (South Adriatic). Biologia Marina Mediterranea, 24:104-105.

Comaschi Caria, I. 1968. Fossili marini e continentali del Quaternario della Sardegna, p. 140229. In Maxia, C. (ed.), Atti del X Congresso Internazionale Studi Sardi (Simposio sul Quaternario Sardo), Cagliari.

Comaschi Caria, I. and Pastore, R. 1959. Fauna del Tirreniano di Margine Rosso (Quartu S. Elena) e di Calamosca (Cagliari). Rendiconti Seminario Facoltà di Scienze Università di Cagliari, 29:85-93. 
Conti, E. and Rossini, L. 1985. I molluschi del Coralligeno del promontorio di Portofino. Oebalia, 11:325-338.

Coppard, S.E. and Campbell, A.C. 2004. Taxonomic significance of spine morphology in the echinoid genera Diadema and Echinothrix. Invertebrate Biology, 123:357-371. https://doi.org/ 10.1111/j.1744-7410.2004.tb00168.x

Coppard, S.E. and Campbell, A.C. 2006a. Systematic significance of tridentate pedicellariae in the echinoid genera Diadema and Echinothrix. Invertebrate Biology, 125:363-378. https:// doi.org/10.1111/j.1744-7410.2006.00068.x

Coppard, S.E. and Campbell, A.C. 2006b. Taxonomic significance of test morphology in the echinoid genera Diadema Gray, 1825 and Echinothrix Peters, 1853 (Echinodermata). Zoosystema, 28:93-112.

Cordeiro, C.A.M.M., Harborne, A.R., and Ferreira, C.E.L. 2014. Patterns of distribution and composition of sea urchin assemblages on Brazilian subtropical rocky reefs. Marine Biology, 161:2221-2232. https://doi.org/10.1007/s00227-014-2500-0

Dafni, J. 1986. A biomechanical model for the morphogenesis of regular echinoid tests. Paleobiology, 12:143-160. https://doi.org/10.1017/s0094837300013622

Deli, T., Ben Attia, M.H., Zitari-Chatti, R., Said, K., and Chatti, N. 2017. Genetic and morphological divergence in the purple sea urchin Paracentrotus lividus (Echinodermata, Echinoidea) across the African Mediterranean coast. Acta Oceanologica Sinica, 36:52-66. https://doi.org/10.1007/s13131-017-1090-3

Donnarumma, L., Sandulli, R., Appolloni, L., and Fulvio Russo, G. 2018. Assessing molluscs functional diversity within different coastal habitats of Mediterranean marine protected areas. Ecological Questions, 29:35-51. https://doi.org/10.12775/eq.2018.021

Donovan, S.K. 1991. The taphonomy of echinoderms: calcareous multi-element skeletons in the marine environment, p. 241-269. In Donovan, S.K. (ed.), The Processes of Fossilisation. Belhaven Press, London.

Donovan, S.K. 2003. Completeness of a fossil record: the Pleistocene echinoids of the Antilles. Lethaia, 36:1-7. https://doi.org/10.1080/00241160310001227

Donovan, S.K. 2005. The fossil record of Diadema in the Caribbean. Coral Reefs, 24:603-605. https://doi.org/10.1007/s00338-005-0032-2

Donovan, S.K. and Gordon, C.M. 1993. Echinoid taphonomy and the fossil record: Supporting evidence from Plio-Pleistocene of the Caribbean. Palaios, 8:304-306. https://doi.org/10.2307/ 3515152

Donovan, S.K. and Jones, B. 1994. Pleistocene echinoids (Echinodermata) from Bermuda and Barbados. Proceedings of the Biological Society of Washington, 107:109-113.

Donovan, S.K., Dixon, H.L., Pickerill, R.K., and Doyle, E.N. 1994. Pleistocene echinoid (Echinodermata) fauna from Southeast Jamaica. Journal of Paleontology, 68:351-358. https://doi.org/10.1017/s0022336000022939

Donovan, S.K., Lewis, D.N., Vincent, H., and Blackman, I.M. 2001. Pleistocene echinoids from Tobago, West Indies. Caribbean Journal of Earth Science, 35:1-12.

Dynowski, J. 2012. Echinoderm remains in shallow-water carbonates at Fernandez Bay, San Salvador Island, Bahamas. Palaios, 27:181-189. https://doi.org/10.2110/palo.2011.p11-015r

Ebert, T.A. 1967. Growth and repair of spines in the sea urchin Strongylocentrotus purpuratus (Stimpson). Biological Bulletin, 133:141-149. https://doi.org/10.2307/1539799

Ebert, T.A. 1968. Growth rates of the sea urchin Strongylocentrotus purpuratus related to food availability and spine abrasion. Ecology, 49:1075-1091. https://doi.org/10.2307/1934491

Ebert, TA. 1988. Growth, regeneration and damage repair of spines of the slate-pencil sea urchin Heterocentrotus mammillatus (L.) (Echinodermata: Echinoidea). Pacific Science, 42:160172.

Ebling, F.J., Hawkins, A.D., Kitching, J.A., Muntz, L., and Pratt, W.M. 1966. The ecology of Lough Ine. XVI. Predation and diurnal migration in Paracentrotus community. Journal of Animal Ecology, 35:559-566. https://doi.org/10.2307/2492

Ellers, O., Johnson, A.S., and Moberg, P.E. 1998. Structural strengthening of urchin skeletons by collagenous sutural ligaments. Biological Bulletin, 195:136-144. https://doi.org/10.2307/ 1542821

Ernst, G., Hähnel, W., and Seibertz, E., 1973. Aktuopaläontologie und Merkmalsvariabilität bei mediterranen Echiniden und Rückschlüsse auf die Ökologie und Artumgrenznug fossiler Formen. Paläontologische Zeitschrift, 47:188-216. https://doi.org/10.1007/bf02985707 
Ernst, G. and Seibertz, E. 1977. Concepts and methods of echinoid biostratigraphy, p. 541-563. In Kauffman, E.G. and Hazel, J.E. (eds.), Concepts and Methods of Biostratigraphy. Dowden, Hutchinson and Ross, Stroudsburg.

Fernandez, C. and Boudouresque, C. 1997. Phenotypic plasticity of Paracentrotus lividus (Echinodermata: Echinoidea) in a lagoonal environment. Marine Ecology Progress Series, 152:145-154. https://doi.org/10.3354/meps152145

Fernandez, C., Caltagirone, A., and Johnson, M. 2001. Demographic structure suggests migration of the sea urchin Paracentrotus lividus in a coastal lagoon. Journal of the Marine Biological Association of the United Kingdom, 81:361-362. https://doi.org/10.1017/ s0025315401003939

Fernandez, C., Ferrat, L., Pergent, G., and Pasqualini, V. 2012. Sea urchin-seagrasses interactions: trophic links in a benthic ecosystem from a coastal lagoon. Hydrobiologia, 699:21-33. https://doi.org/10.1007/s10750-012-1151-8

Fernandez, C., Pasqualini, V., Johnson, M., Ferrat, L., Caltagirone, A., and Boudouresque, C.F. 2003. Stock evaluation of the sea urchin Paracentrotus lividus in a lagoonal environment, $p$. 319-323. In Féral, J.P. and David, B. (eds.), Echinoderm Research 2001. A.A. Balkema, Rotterdam.

Ferreira Soares, A., Callapez, P.M., and Fonseca Marquez, J. 2007. The Farol Deposit (Depósito do Farol) - a Pleistocene beach deposit from Cape Mondego (Figueira da Foz, West Central Portugal). Ciências da Terra, 16:163-173.

Fontana Zanco, E. 1933. Nuove osservazioni sul piano Tirrenico dei dintorni di Cagliari. Rendiconti Seminario Facoltà di Scienze, Università di Cagliari, 3:116-125.

Geys, J.F. and Marquet, R. 1979. Strongylocentrotus pallidus (G.O. Sars, 1871), an addition to the echinoderm fauna of the Scaldisian (Pliocene) in Belgium. Mededelingen van de Werkgroep voor Tertiare en Kwartaire Geologie, 16:131-138.

Giacobbe, S. and Renda, W. 2018. Infralittoral molluscs from the Scilla cliff (Strait of Messina, Central Mediterranean). Biodiversity Journal, 9:255-270. https://doi.org/10.31396/ biodiv.jour.2018.9.3.255.270

Gianguzza, P., Chiantore, M., Bonaviri, C., Cattaneo-Vietti, R., Vielmini, I., and Riggio, S. 2006. The effects of recreational Paracentrotus lividus fishing on distribution patterns of sea urchins at Ustica Island MPA (Western Mediterranean, Italy). Fisheries Research, 81:37-44. https:// doi.org/10.1016/j.fishres.2006.06.002

Girard, D., Clemente, S., Toledo-Guedes, K., Brito, A., and Hernández, J.C. 2011. A mass mortality of subtropical intertidal populations of the sea urchin Paracentrotus lividus: analysis of potential links with environmental conditions. Marine Ecology, 33:377-385. https://doi.org/ 10.1111/j.1439-0485.2011.00491.x

Gordon, C.M. 1991. The poor fossil record of Echinometra (Echinodermata: Echinoidea) in the Caribbean region. Journal of the Geological Society of Jamaica, 28:37-41.

Gordon, C.M. and Donovan, S.K. 1992. Disarticulated echinoid ossicles in paleoecology and taphonomy: The last interglacial Falmouth Formation of Jamaica. Palaios, 7:157-166. https:// doi.org/10.2307/3514926

Greenstein, B.J. 1989. Mass mortality of the West-Indian echinoid Diadema antillarum (Echinodermata: Echinoidea): A natural experiment in taphonomy. Palaios, 4:487-492. https://doi.org/10.2307/3514593

Greenstein, B.J. 1991. An integrated study of echinoid taphonomy: Predictions for the fossil record of four echinoid families. Palaios, 6:519-540. https://doi.org/10.2307/3514916

Greenstein, B.J. 1992. Taphonomic bias and the evolutionary history of the family Cidaridae (Echinodermata: Echinoidea). Paleobiology, 18:50-79. https://doi.org/10.1017/ s0094837300012215

Greenstein, B.J. 1993a. Is the fossil record of regular echinoids so poor? A comparison of living and subfossil assemblages: Palaios, 8:587-601. https://doi.org/10.2307/3515034

Greenstein, B.J. 1993b. The effect of life habit on the preservation potential of echinoids, p. 5574. In White, B.N. (ed.), Proceedings of the $6^{\text {th }}$ Symposium on the Geology of the Bahamas: Bahamian Field Station, San Salvador, Bahamas.

Greenstein, B.J. 1995. The effects of life habit and test microstructure on the preservation potential of echinoids in Graham's Harbour, San Salvador Island, Bahamas. Geological Society of America Special Paper, 300:177-188. https://doi.org/10.1130/0-8137-2300-0.177 
Grun, T.B., Kroh, A., and Nebelsick, J.H. 2017. Comparative drilling predation on time-averaged phosphatized and nonphosphatized assemblages of the minute clypeasteroid echinoid Echinocyamus stellatus from Miocene offshore sediments (Globigerina Limestone Formation, Malta). Journal of Palaeontology, 91:633-642. https://doi.org/10.1017/ jpa.2016.123

Grun, T.B., Mancosu, A., Belaústegui, Z., and Nebelsick, J.H. 2018a. The taphonomy of Clypeaster: a paleontological tool to identify stable structures in natural shell systems. Neues Jahrbuch für Geologie und Paläontologie, 289:189-202. https://doi.org/10.1127/njgpa/2018/ 0737

Grun, T.B. and Nebelsick, J.H. 2018a. Structural design of the minute clypeasteroid echinoid Echinocyamus pusillus. Royal Society Open Science, 5:171323. https://doi.org/10.1371/ journal.pone.0204432

Grun, T.B. and Nebelsick, J.H. 2018b. Structural design of the echinoid's trabecular system. PLoS ONE 13:e0204432. https://doi.org/10.1371/ journal.pone.0204432

Grun, T.B., Sievers, D., and Nebelsick, J.H. 2014. Drilling predation on the clypeasteroid echinoid Echinocyamus pusillus from the Mediterranean Sea (Giglio, Italy). Historical Biology, 26:745-757. https://doi.org/10.1080/08912963.2013.841683

Grun, T.B., von Scheven, M., Bischoff, M., and Nebelsick, J.H. 2018b. Structural stress response of segmented natural shells: a numerical case study on the clypeasteroid echinoid Echinocyamus pusillus. Journal of the Royal Society Interface, 15:20180164. https://doi.org/ 10.1098/rsif.2018.0164

Guidetti, P. 2004. Consumers of sea urchins, Paracentrotus lividus and Arbacia lixula, in shallow Mediterranean rocky reef. Helgoland Marine Research, 58:110-116. https://doi.org/10.1007/ s10152-004-0176-4

Guidetti, P. and Mori, M. 2005. Morpho-functional defences of Mediterranean sea urchins, Paracentrotus lividus and Arbacia lixula, against fish predators. Marine Biology, 147:797-802. https://doi.org/10.1007/s00227-005-1611-z

Gutierrez-Mas, J.M. 2011. Glycymeris shell accumulations as indicators of recent sea-level changes and high-energy events in Cadiz Bay (SW Spain). Estuarine, Coastal and Shelf Science, 92:546-554. https://doi.org/10.1016/j.ecss.2011.02.010

Hall-Spencer, J. 1998. Conservation issues relating to maerl beds as habitats for molluscs. Journal of Conchology Special Publication, 2:271-286.

Issel, A. 1914. Lembi fossiliferi quaternari e recenti osservati nella Sardegna meridionale dal Prof. Lovisato. Rendiconti Reale Academia dei Lincei, Classe di Scienze Fisiche, Matematiche e Naturali, 23:759-770.

Jacinto, D. and Cruz, T. 2012. Paracentrotus lividus (Echinodermta: Echinoidea) attachment force and burrowing behavior in rocky shores of SW Portugal. Zoosymposia, 7:231-240. https://doi.org/10.11646/zoosymposia.7.1.21

Kersting, D.K., Cebrian, E., Verdura, J., and Ballesteros, E. 2017. A new Cladocora caespitosa population with unique ecological traits. Mediterranean Marine Science, 18:38-42. https:// doi.org/10.12681/mms.1955

Kidwell, S.M. and Baumiller, T. 1990. Experimental disintegration of regular echinoids: roles of temperature, oxygen and decay thresholds. Paleobiology, 16:247-271. https://doi.org/ $10.1017 / \mathrm{s} 0094837300009982$

Kidwell, S.M. and Holland, S.M. 1991. Field description of coarse bioclastic fabric. Palaios, 6:426-434. https://doi.org/10.2307/3514967

Kier, P.M. 1977. The poor fossil record of the regular echinoid. Palaeobiology, 3:168-174. https:// doi.org/10.1017/s0094837300005248

Kier, P.M. 1982. Rapid evolution in echinoids. Palaeontology, 25:1-9.

Koehler, R. 1927. Les échinoderms des mers d'Europe, Tome II. Gaston Doin et Cie, Paris.

Koukouras, A., Kühlmann, D., Voultsiadou, E., Vafidis, D., Dounas, C., Chintiroglou, C., and Koutsoubas, D. 1998. The macrofaunal assemblage associated with the scleractinian coral Cladocora caespitosa (L.) in the Aegean Sea. Annales de l'Institut Océanographique, 74:97114.

Kroh, A. 2005. Catalogus Fossilium Austriae, Band 2, Echinoidea Neogenica. Österreichische Akademie der Wissenschaften, Vienna. 
Kroh, A. and Nebelsick, J.H. 2010. Echinoderms and Oligo-Miocene carbonate systems: potential applications in sedimentology and environmental reconstruction. International Association of Sedimentologists, Special Publications, 42:201-228. https://doi.org/10.1002/ 9781118398364.ch12

Kroh, A. and Smith, A.B. 2010. The phylogeny and classification of post-Palaeozoic echinoids. Journal of Systematic Palaeontology, 8:147-212. https://doi.org/10.1080/ 14772011003603556

Lamarck, J.B. 1816. Histoire naturelle des animaux sans vertèbres. Tome second. Déterville et Verdière, Paris.

Lecca, L. and Carboni, S. 2007. The Tyrrhenian Section of San Giovanni di Sinis (Sardinia): Stratigraphic record of an irregular single high stand. Rivista Italiana di Paleontologia e Stratigrafia, 113:509-523.

Lewis, R.D., Schein, J.P., and Sadler, M.T. 2000. Echinoid skeletal fragments in sea-floor sediment, San Salvador, Bahamas: Fidelity studies using sand-sized material. Geological Society of America Abstracts with Programs, 32:A-446.

Lipkin, Y. and Safriel, U. 1971. Intertidal zonation on rocky shores at Mikhmoret (Mediterranean, Israel). Journal of Ecology, 59:1-30. https://doi.org/10.2307/2258448

Loi, B., Guala, I., Pires Da Silva, R., Brundu, G., Baroli, M., and Farina, S. 2017. Hard time to be parents? Sea urchin fishery shifts potential reproductive contribution of population onto the shoulders of the young adults. PeerJ, 5:e3067. https://doi.org/10.7717/peerj.3067

Lozano, J., Galera, J., López, S., Turon, X., Palacín, C., and Morera, G. 1995. Biological cycles and recruitment of Paracentrotus lividus (Echinodermata: Echinoidea) in two contrasting habitats. Marine Ecology Progress Series, 122:179-191.

Madeira, P., Kroh, A., Cordeiro, R., Meireles, R., and Ávila, S.P. 2011. The fossil echinoids of Santa Maria Island, Azores (Northern Atlantic Ocean). Acta Geologica Polonica, 61:243-264.

Mancosu, A. and Nebelsick, J.H. 2013. Multiple routes to mass accumulations of clypeasteroid echinoids: A comparative analysis of Miocene echinoid beds of Sardinia. Palaeogeography, Palaeoclimatology, Palaeoecology, 374:173-186. https://doi.org/10.1016/ j.palaeo.2013.01.015

Mancosu, A. and Nebelsick, J.H. 2017. Ecomorphological and taphonomic gradient of clypeasteroid-dominated echinoid assemblages along a mixed siliciclastic-carbonate shelf from the early Miocene of northern Sardinia, Italy. Acta Palaeontologica Polonica, 62:627646. https://doi.org/10.4202/app.00357.2017

Mancosu, A. and Nebelsick, J.H. 2019. Palaeoecology of sublittoral Miocene echinoids from Sardinia: A case study for substrate controls of faunal distributions. Journal of Paleontology, 93:764-784. https://doi.org/10.1017/jpa.2019.4

Mancosu, A., Nebelsick, J.H., Kroh, A. and Pillola, G.L. 2015. Echinoid shell beds in siliciclastic shelf environments: three examples from the Miocene of Sardinia, Italy. Lethaia, 48:83-99. https://doi.org/10.1111/let.12090

Mitchell, S.F., James, S.A., and Brown, I.C. 2006. A late Pleistocene progradational clastic shoreface succession in Jamaica: implications for the preservation potential of the echinoid Leodia. Lethaia, 39:321-327. https://doi.org/10.1080/00241160600847553

Moffat H.A. and Bottjer D.J. 1999. Echinoid concentration beds: two examples from the stratigraphic spectrum. Palaeogeography, Palaeoclimatology, Palaeoecology, 149:329-348. https://doi.org/10.1016/s0031-0182(98)00210-7

Mooi, R., David, B., Fell, J.F., and Chone, T. 2000. Three new species of bathyal cidaroids (Echinodermata: Echinoidea) from the Antartic region. Proceedings of the Biological Society Washington, 113:224-237.

Mortensen, T. 1903. The Danish Ingolf-Expedition 1895-1896. Vol. 4, No. 2. Echinoidea, pt. 1. Bianco Luno, Copenhagen.

Mortensen, T. 1927. Handbook of the Echinoderms of the British Isles. University Press, Oxford.

Mortensen, T. 1928. A Monograph of the Echinoidea. I, Cidaroidea. C.A. Reitzel and Oxford University Press, Copenhagen and London.

Mortensen, T. 1935. A monograph of the Echinoidea. II. Bothriocidaroida, Melonechinoida, Lepidocentroida, and Stirodonta. C.A. Reitzel and Oxford University Press, Copenhagen and London.

Mortensen, T. 1940. A Monograph of the Echinoidea, III, 1. Lepidocentroida and Stirodonta. C.A. Reitzel, Copenhagen. 
Mortensen, T. 1943, A Monograph of the Echinoidea, III, 3. Camaradonta. II. Echinidae, Strongylocentrotidae, Parasaleniidae, Echinometridae. C.A. Reitzel, Copenhagen.

Morton, B. and Puljas, S. 2017. The biology and functional morphology of Mytilaster minimus (Bivalvia: Mytiloidea: Mytilidae) from the intertidal dinaric karst of Croatia (Adriatic Sea). Journal of the Marine Biological Association of the United Kingdom, 98:1999-2016. https:// doi.org/10.1017/s0025315417001497

Nebelsick, J.H. 1992a. The northern Bay of Safaga (Red Sea, Egypt): An actuopalaeontological approach III. Distribution of echinoids. Beiträge zur Paläontologie von Österreich, 17:5-79.

Nebelsick, J.H. 1992b. Echinoid distribution by fragment identification in the Northern Bay of Safaga, Red Sea, Egypt. Palaios, 7:316-328. https://doi.org/10.2307/3514976

Nebelsick, J.H. 1995. Actuopalaeontological investigations on echinoids: The potential for taphonomic interpretation, p. 209-214. In Emson, R.H., Smith, A.B., and Campbell, A.C. (eds.), Echinoderm Research. A.A. Balkema, Rotterdam.

Nebelsick, J.H. 1996. Biodiversity of shallow-water Red Sea echinoids: implications for the fossil record. Journal of the Marine Biological Association of the United Kingdom, 76:185-194. https://doi.org/10.1017/s0025315400029118

Nebelsick, J.H. 2020. Ecology of clypeasteroids, p. 315-332. In Lawrence, J.M. (ed.), Sea Urchins: Biology and Ecology (4th Edition). Elsevier, Amsterdam. https://doi.org/10.1016/ B978-0-12-819570-3.00018-4

Nebelsick, J.H. and Kampfer, S. 1994. Taphonomy of Clypeaster humilis and Echinodiscus auritus from the Red Sea, p. 803-808. In David, B., Guille, A., Féral J.P., and Roux, M. (eds.), Echinoderms through Time. A.A. Balkema, Rotterdam.

Nebelsick, J.H. and Kroh, A. 2002. The stormy path from life to death assemblages: The formation and preservation of mass accumulation of fossil sand dollars. Palaios, 17:378-393. https://doi.org/10.1669/0883-1351(2002)017<0378:tspflt>2.0.co;2

Néraudeau, D. and Masrour, M. 2008. Évolution de la biodiversité et de la distribution paléobiogéographique des échinides sur les côtes atlantiques du Maroc du Tortonien à l'Actuel. Geodiversitas, 30:211-232.

Ouréns, R., Freire, J., Vilar, J.A., and Fernández, L. 2014. Influence of habitat and population density on recruitment and spatial dynamics of the sea urchin Paracentrotus lividus: implications for harvest refugia. ICES Journal of Marine Science, 71:1064-1072. https:// doi.org/10.1093/icesjms/fst201

Öztürk, B. 2011. Scaphopod species (Mollusca) of the Turkish Levantine and Aegean seas. Turkish Journal of Zoology, 35:199-211.

Öztürk, B., Doğan, A., Bitilis-Bakir, B., and Salman, A. 2014. Marine molluscs of the Turkish coasts: an updated checklist. Turkish Journal of Zoology, 38:5-137.

Peharda, M., Richardson, C.A., Onofri, V., Bratoš, A., and Crnčević, M. 2002. Age and growth of the bivalve Arca noae L. in the Croatian Adriatic Sea. Journal Molluscan Studies, 68:307310. https://doi.org/10.1093/mollus/68.4.307

Pérès, J.M. and Picard, J. 1964. Nouveau manuel de Bionomie Bentique de la Mer Méditerranèe. Recueil des Travaux de la Station Marine d'Endoume, 31:5-137.

Phelan, T. 1970. A field guide to the cidaroid echinoids of the Northwestern Atlantic Ocean, Gulf of Mexico, and the Caribbean Sea. Smithsonian Contributions to Zoology, 40:1-67. https:// doi.org/10.5479/si.00810282.40

Pitacco, V., Orlando-Bonaca, M., Mavrič, B., and Lipej, L. 2014. Macrofauna associated with a bank of Cladocora caespitosa (Anthozoa, Scleractinia) in the Gulf of Trieste (Northern Adriatic). Annales Series Historia Naturalis, 24:1-14.

Poursanidis, D., Koutsoubas, D., Arvanitidis, C., and Chatzigeorgiou, G. 2016. ReefMedMol: Mollusca from the infralittoral rocky shores - the biocoenosis of photophilic algae - in the Mediterranean Sea. Biodiversity Data Journal, 4:e7516. https://doi.org/10.3897/bdj.4.e7516

Privitera, D., Chiantore, M., Mangialajo, L., Glavic, N., Kozul, W., and Cattaneo-Vietti, R. 2008. Inter-and intra-specific competition between Paracentrotus lividus and Arbacia lixula in resource limited barren areas. Journal of Sea Research, 60:184-192. https://doi.org/10.1016/ j.seares.2008.07.001

Ragaini, L. 1997. Echinoid fauna from the Quaternary fringing reef of Aqaba (Jordan). Paleontographia Italica, 84:1-19. 
Régis, M.B. 1977. Organisation microstructurale du stéréom de l'Echinoïde Paracentrotus lividus (Lamarck) et ses éventuelles incidences phyiologiques. Comptes rendus hebdomadaires des séances de l'Académie des Sciences, Série D, Sciences naturelles, 285:189-192.

Régis, M.B. 1979. Particularités microstructurales du squelette de Paracentrotus lividus et Arbacia lixula: Rapports avec l'écologie et éthologie de ces échinoïdes. Marine Biology, 54:373-382. https://doi.org/10.1007/bf00395443

Rholing, E.J., Grant, K., Hemleben, C.H., Siddall, M., Hoogakker, B.A.A., Bolshaw, M., and Kucera, M. 2007. High rates of sea-level rise during the last interglacial period. Nature Geoscience, 1:38-42. https://doi.org/10.1038/ngeo.2007.28

Riedl, R. 1983. Fauna und Flora des Mittelmeeres. Paul Parey, Berlin.

Rolán, E. 2005. Malacological fauna from the Capo Verde Archipelago, Part 1: Polyplacophora and Gastropoda. ConchBooks Verlag, Hackenheim, Germany.

Rosenberg, G., Moretzsohn, F., and García, E.F. 2009. Gastropoda (Mollusca) of the Gulf of Mexico, p. 579-699. In Felder, D.L. and Camp, D.K. (eds.), Gulf of Mexico-Origins, Waters, and Biota. Biodiversity. Texas A\&M University Press, College Station, Texas.

Rubio, F. and Rolán, E. 2002. Revisione del genere Clanculus (Gastropoda: Trochidae) per l'Atlantico orientale. Edizioni Evolver, Roma.

Rufino, M.M., Gaspar, M.B., Pereira, A.M., Maynou, F., and Monteiro, C.C. 2010. Ecology of megabenthic bivalve communities from sandy beaches on the south coast of Portugal. Scientia Marina, 74:163-178. https://doi.org/10.3989/scimar.2010.74n1163

Russo, G.F., Chessa, L.A., Vinci, D., and Fresi, E. 1991. Molluscs of Posidonia oceanica beds in the Bay of Porto Conte (North-Western Sardinia): Zonation pattern, seasonal variability and geographical comparison. Posidonia Newsletter, 4:5-14.

Russo, G.F., Fraschetti, S., and Terlizzi, A. 2002. Population ecology and production of Bittium latreilli (Gastropoda, Cerithidae) in a Posidonia oceanica seagrass bed. Italian Journal of Zoology, 69:215-222. https://doi.org/10.1080/11250000209356462

Sala, E. 1997. Fish predators and scavengers of the sea urchin Paracentrotus lividus in protected areas of the north-west Mediterranean Sea. Marine Biology, 129:531-539. https:// doi.org/10.1007/s002270050194

Sala, E., Ribes, M., Hereu, B., Zabala, M., Alvà, V., Coma, R., and Garrabou, J. 1998. Temporal variability in abundance of the sea urchins Paracentrotus lividus and Arbacia lixula in the northwestern Mediterranean: comparison between a marine reserve and an unprotected area. Marine Ecology Progress Series, 168:135-145. https://doi.org/10.3354/meps168135

Sala, E. and Zabala, M. 1996. Fish predation and the structure of the sea urchin Paracentrotus lividus populations in the NW Mediterranean. Marine Ecology Progress Series, 140:71-81. https://doi.org/10.3354/meps140071

Schein, J.P. and Lewis, R.D. 2001. The relationship between living echinoid populations and their skeletal remains in the sea-floor sediment, San Salvador, Bahamas, p. 163-174. In Greenstein, B.J. and Carney, C.J. (eds.), Proceedings of the $10^{\text {th }}$ Symposium on the Geology of the Bahamas, and other carbonate regions. Bahamian Field Station, San Salvador, Bahamas.

Sciberras, M., Rizzo, M., Mifsud, J.R., Camilleri, K., Borg, J.A., Lanfranco, E., and Schembri, P.J. 2009. Habitat structure and biological characteristics of a maerl bed off the northeastern coast of the Maltese Islands (central Mediterranean). Marine Biodiversity, 39:251-264. https:/ /doi.org/10.1007/s12526-009-0017-4

Seilacher, A. 1979. Constructional morphology of sand dollars. Palaeobiology, 5:191-221. https:/ /doi.org/10.1017/s0094837300006527

Sessa, J.A., Callapez, P.M., Dinis, P.A., and Hendy, A.J.W. 2013. Paleoenvironmental and paleobiogeographical implications of a Middle Pleistocene mollusc assemblage from the marine terraces of Baía Das Pipas, southwest Angola. Journal of Paleontology, 87:10161040. https://doi.org/10.1666/12-119

Sievers, D. and Nebelsick, J.H. 2018. Fish predation on a Mediterranean echinoid: identification and preservation potential. Palaios, 33:47-54. https://doi.org/10.2110/palo.2017.041

Sivan, D., Potasman, M., Almogi-Labin, A., Bar-Yosef Mayer, D.E., Spanier, E., and Boaretto, E. 2006. The Glycymeris query along the coast and shallow shelf of Israel, southeast Mediterranean. Palaeogeography, Palaeoclimatology, Palaeoecology, 233:134-148. https:// doi.org/10.1016/j.palaeo.2005.09.018 
Smiser, J.S. 1933. A study of the echinoid fragments in the Cretaceous rocks of Texas. Journal of Paleontology, 7:123-163.

Smith, A.B. 1980. Stereom microstructure of the echinoid test. Special Papers in Palaeontology, 25. The Palaeontological Association, London.

Smith, A.B. 1984. Echinoid Palaeobiology. George Allen and Unwin Ltd, London.

Smith, A.B. 1988. Phylogenetic relationship, divergence times and rates of molecular evolution for camarodont sea urchins. Molecular Biology and Evolution, 5:345-365. https://doi.org/ 10.1093/oxfordjournals.molbev.a040507

Smith, A.B. 2005. Growth and form in echinoids: the evolutionary interplay of plate accretion and plate addition, p. 181-195. In Briggs, D.E.G. (ed.), Evolving Form and Function: Fossils and Development. New Haven, Yale Peabody Museum Publications, New Haven.

Smith, A.B. 2007. Intrinsic versus extrinsic biases in the fossil record: contrasting the fossil record of echinoids in the Triassic and early Jurassic using sampling data, phylogenetic analysis, and molecular clocks. Paleobiology, 33:310-323. https://doi.org/10.1666/06073.1

Smith, A.B. and Kroh, A. (eds.) 2011. The Echinoid Directory. World Wide Web electronic publication. http://www.nhm.ac.uk/research-curation/projects/echinoid-directory [Accessed 20/04/2020]. https://www.nhm.ac.uk/our-science/data/echinoid-directory/

Smith, A.B. and Rader, W.L. 2009. Echinoid diversity, preservation potential and sequence stratigraphical cycles in the Glen Rose Formation (early Albian, Early Cretaceous), Texas, USA. Palaeobiodiversity and Palaeoenvironments, 89:7-52. https://doi.org/10.1007/s12549009-0002-8

Sørensen, A.M. and Surlyk, F. 2015. Rocky shore taphonomy - A comparative study of modern and Late Cretaceous analogues. Palaeogeography, Palaeoclimatology, Palaeoecology, 423:44-52. https://doi.org/10.1016/j.palaeo.2015.01.026

Spadini, V. 2006. II genere Clanculus Monfort, 1810 (Gastropoda: Trochidae) nel Pliocene senese (Toscana, Italia). Atti Società Italiana Scienze Naturali Museo Civico di Storia Naturale Milano, 147:211-237.

Spano, C. 1982. Fauna del Tirreniano-tipo di Is Mesas-Calamosca (Sardegna Meridionale), pp. 65-101. In Ulzega, A. and Ozer, A. (eds.), Compte-Rendus de l'Excursion-Table ronde sur le Thyrrenien de Sardaigne. INQUA, 21-28 Aprile 1980, Stabilimento Tipografico Editoriale Fossataro S.p.A., Cagliari.

Spano, C. 1993a. Signification bioécologique et bathymétrique des paléocommunautés pleistocenique des côtes méridionales de la Sardaigne. Estudios Sobre el Cuaternario, 2742.

Spano, C. 1993b. La faune bentique des différents niveau a Strombus bubonius de Is MesasCala Mosca (Sardaigne méridionale, Italie). Estudios Sobre el Cuaternario, 89-98.

Stefanini, G. 1911. Di alcune Arbacia fossili. Rivista Italiana di Paleontologia, 17:51-52.

Sulis, A. and Annis, A. 2014. Morphological response of a sandy shoreline to a natural obstacle at Sa Mesa Longa Beach, Italy. Coastal Engineering, 84:10-22. https://doi.org/10.1016/ j.coastaleng.2013.10.014

Taylor, J.D. 1987. Feeding ecology of some common intertidal neogastropods at Djerba, Tunisia. Vie Milieu, 37:13-20.

Telford, M. 1985. Domes, arches and urchins: The skeletal architecture of echinoids (Echinodermata). Zoomorphology, 105:114-124. https://doi.org/10.1007/bf00312146

Thompson, J.R., Posenato, R., Bottjer. D.J., and Petsios, E. 2019. Echinoids from the Tesero Member (Werfen Formation) of the Dolomites (Italy): implications for extinction and survival of echinoids in the aftermath of the end-Permian mass extinction. PeerJ, 7:e7361. https:// doi.org/10.7717/peerj.7361

Tortonese, E. 1965. Echinodemata: Fauna d'Italia. Calderini, Bologna.

Trigui El-Menif, N., Kefi, F.J., Ramdani, M., Flower, R., and Boumaiza, M. 2007. Habitat and associated fauna of Lithophaga lithophaga (Linné 1758) in the Bay of Bizerta (Tunisia). Journal of Shellfish Research, 26:569-574. https://doi.org/10.2983/07308000(2007)26[569:haafol]2.0.co;2

Turon, X., Giribet, G., López, S., and Palacín, C. 1995. Growth and population structure of Paracentrotus lividus (Echinodermta: Echinoidea) in two contrasting habitats. Marine Ecology Progress Series, 122:193-204. https://doi.org/10.3354/meps122193

Ulzega, A. and Hearty, P.J. 1986. Geomorphology, stratigraphy and geochronology of Late Quaternary marine deposits in Sardinia. Zeitschrift für Geomorphologie, Supplementary Issues, 62:119-129. 
Ulzega, A. and Ozer, A. 1982. Compte-Rendus de l'Excursion-Table ronde sur le Thyrrenien de Sardaigne. INQUA, 21-28 Aprile 1980, Stabilimento Tipografico Editoriale Fossataro S.p.A., Cagliari.

Urra, J., Ramírez, Á.M., Marina, P., Salas, C., Gofas, S., and Rueda, J.L. 2013. Highly diverse molluscan assemblages of Posidonia oceanica meadows in northwestern Alboran Sea (W Mediterranean): Seasonal dynamics and environmental drivers. Estuarine, Coastal and Shelf Science, 117:136-147. https://doi.org/10.1016/j.ecss.2012.11.005

Vasconcelos, P., Cúrdia, J., Castro, M., and Gaspar, M.B. 2007. The shell of Hexaplex (Trunculariopsis) trunculus (Gastropoda: Muricidae) as a mobile hard substratum for epibiotic polychaetes (Annelida: Polychaeta) in the Ria Formosa (Algarve coast-southern Portugal). Hydrobiologia, 575:161-172. https://doi.org/10.1007/s10750-006-0367-x

Verlaque, M. 1984. Biologie des juveniles de l'oursin herbivore Paracentrotus lividus (Lamarck), sélectivité du broutage et impact de l'espèce sur les communautés algales de substrat roucheux en Corse (Méditerranée, France). Botanica Marina, 27:401-424. https://doi.org/ 10.1515/botm.1984.27.9.401

Verlaque, M. 1987. Relations entre Paracentrotus lividus (Lamarck) et le phytobenthos de Méditerranée occidentale, p. 5-36. In Boudouresque, C.F. (ed.), Colloque international sur Paracentrotus lividus et les oursins comestibles, GIS Posidonie, Marseilles.

Wangensteen, O.S., Turon, X., Pérez-Portela, R., and Palacín, C. 2012. Natural or naturalized? Phylogeography suggests that the abundant sea urchin Arbacia lixula is a recent colonizer of the Mediterranean. PLoS ONE, 7:e45067. https://doi.org/10.1371/journal.pone.0045067

WoRMS Editorial Board, 2019. World Register of Marine Species. Available from http:// www.marinespecies.org at VLIZ. Accessed 2019-09-06.

Zavodnik D. 1980. Distribution of Echinodermata in the north Adriatic insular region. Acta Adriatica, 21:437-468.

Zavodnik, D. 2003. Marine fauna of Mljet National Park (Adriatic Sea, Croatia) 2: Echinodermata. Acta Adriatica, 44:101-157.

Zunino, S., Pitacco, V., Mavrič, B., Orlando-Bonaca, M., Kružić, P., and Lipej, L. 2018. The ecology of the Mediterranean stony coral Cladocora caespitosa (Linnaeis, 1767) in the Gulf of Trieste (northern Adriatic Sea): a 30-year long story. Marine Biology Research, 14:307320. https://doi.org/10.1080/17451000.2017.1408915

Župan, I., Peharda, M., Ezgeta-Balić, D., and Šarić, T. 2012. Noah's ark shell (Arca noae Linnaeus, 1758) - What do we need to know for starting up its aquaculture? Croatian Journal of Fisheries, 70:71-80. 